\title{
Methods to study organogenesis in decapod crustacean larvae. I. larval rearing, preparation, and fixation
}

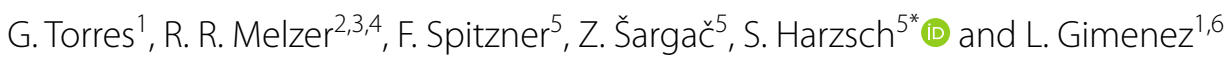

\begin{abstract}
Crustacean larvae have served as distinguished models in the field of Ecological Developmental Biology ("EcoDevo") for many decades, a discipline that examines how developmental mechanisms and their resulting phenotype depend on the environmental context. A contemporary line of research in EcoDevo aims at gaining insights into the immediate tolerance of organisms and their evolutionary potential to adapt to the changing abiotic and biotic environmental conditions created by anthropogenic climate change. Thus, an EcoDevo perspective may be critical to understand and predict the future of organisms in a changing world. Many decapod crustaceans display a complex life cycle that includes pelagic larvae and, in many subgroups, benthic juvenile-adult stages so that a niche shift occurs during the transition from the larval to the juvenile phase. Already at hatching, the larvae possess a wealth of organ systems, many of which also characterise the adult animals, necessary for autonomously surviving and developing in the plankton and suited to respond adaptively to fluctuations of environmental drivers. They also display a rich behavioural repertoire that allows for responses to environmental key factors such as light, hydrostatic pressure, tidal currents, and temperature. Cells, tissues, and organs are at the basis of larval survival, and as the larvae develop, their organs continue to grow in size and complexity. To study organ development, researchers need a suite of state-ofthe-art methods adapted to the usually very small size of the larvae. This review and the companion paper set out to provide an overview of methods to study organogenesis in decapod larvae. This first section focuses on larval rearing, preparation, and fixation, whereas the second describes methods to study cells, tissues, and organs.
\end{abstract}

Keywords: EcoDevo, MorphoEvoDevo, Brachyura, Decapoda, Larval rearing, Ecophysiology, Organogenesis, Global ocean change

\section{Background}

Crustaceans represent one of the most species-rich animal groups in our oceans and display a large diversity of sizes, morphologies, life-styles, and life histories

\footnotetext{
*Correspondence: steffen.harzsch@uni-greifswald.de

${ }^{5}$ Department of Cytology and Evolutionary Biology, Zoological Institute and Museum, University of Greifswald, Soldmannstrasse 23,

17498 Greifswald, Germany

Full list of author information is available at the end of the article We dedicate this review to Klaus Anger who introduced us to the incredible world of tiny crustacean larvae with utmost patience
}

(reviews e.g. [1-3]). Specifically, representatives of the crustaceans have colonized habitats extending from the deepest ocean trenches and hydrothermal vents, across the vast water bodies of the world's oceans, through intertidal and supratidal coastal habitats. Crustaceans have also representatives occurring in anchihaline caves, inland freshwater ecosystems including endorheic lakes, and terrestrial habitats such as desert saltpans, epiphytic bromeliads in mountain forests, or rocky plateaus of coastal and oceanic islands. Decapoda is a highly diverse subgroup of malacostracan crustaceans that includes well-known representatives such as 
ornamental shrimps, clawed and spiny lobsters, hermit crabs, and true crabs. Many decapods represent key species in estuarine, intertidal, and coastal areas where they can have such a high abundance that changes in their population structure may directly influence the structure of the whole ecosystem [4, 5]. Decapods inhabiting estuaries or intertidal zones are adapted to enduring tremendous variations in temperature, $\mathrm{pH}$, and salinity at a daily scale as the consequence of the tides. Decapoda also embraces many species with global invasive potential signifying their ability to adapt to new and changing environments (reviews [5-9]).
Similar to many other marine benthic animals, many decapod crustaceans display a complex life cycle in that they occupy different habitats during ontogeny, and undergo niche shifts during the transition from larvae to the juvenile phase. The life cycle includes pelagic larvae and in most species benthic juvenile-adult stages (Figs. 1, 2; reviews [10-16]). The ontogenetic change in habitat represents an important link in marine food webs (bentho-pelagic coupling). The larval phase, which is essential for dispersal (review [17, 18]), occurs in the pelagic environment, and many larvae of marine crustaceans actively feed (review $[19,20]$ ) and grow by

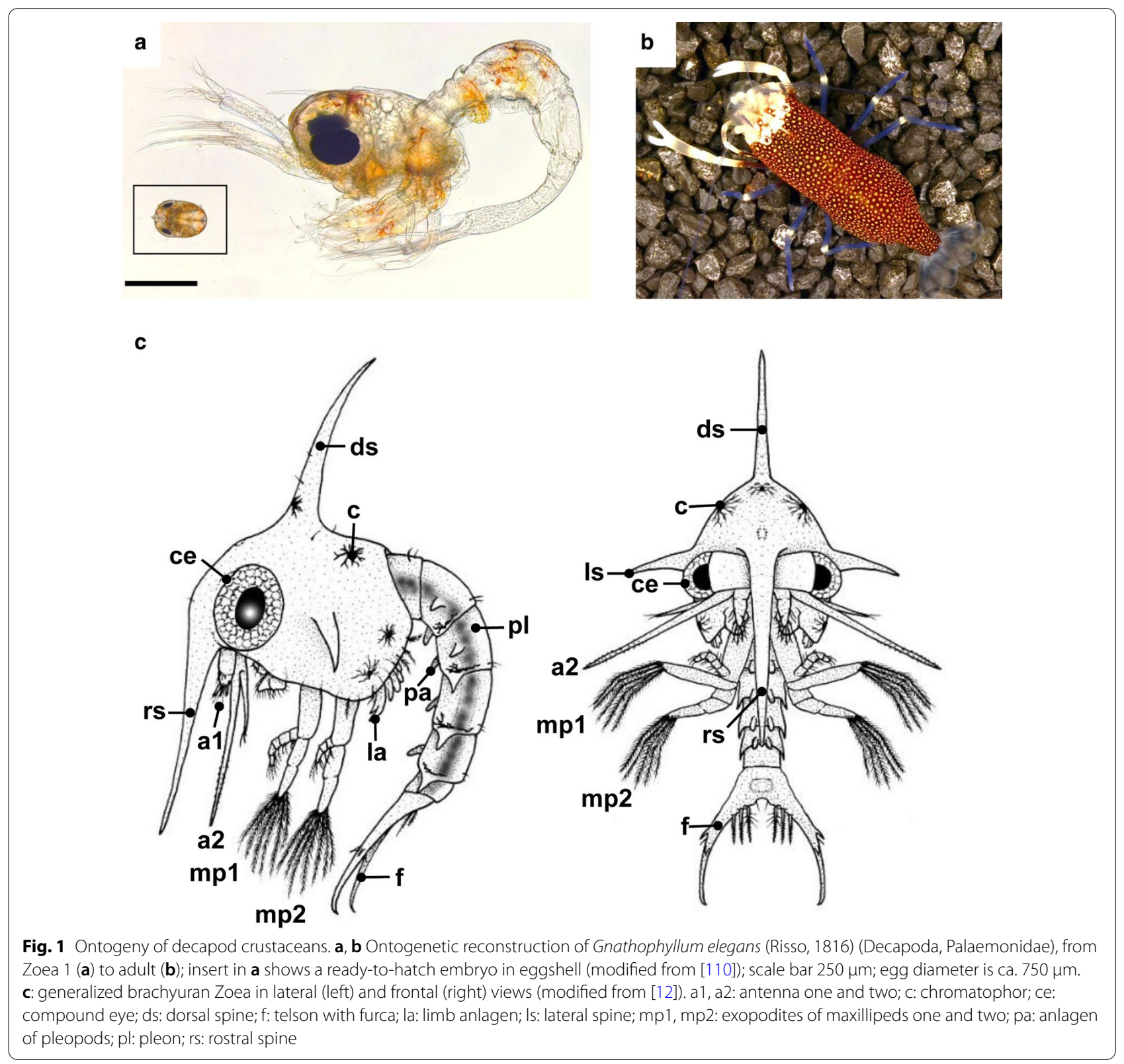



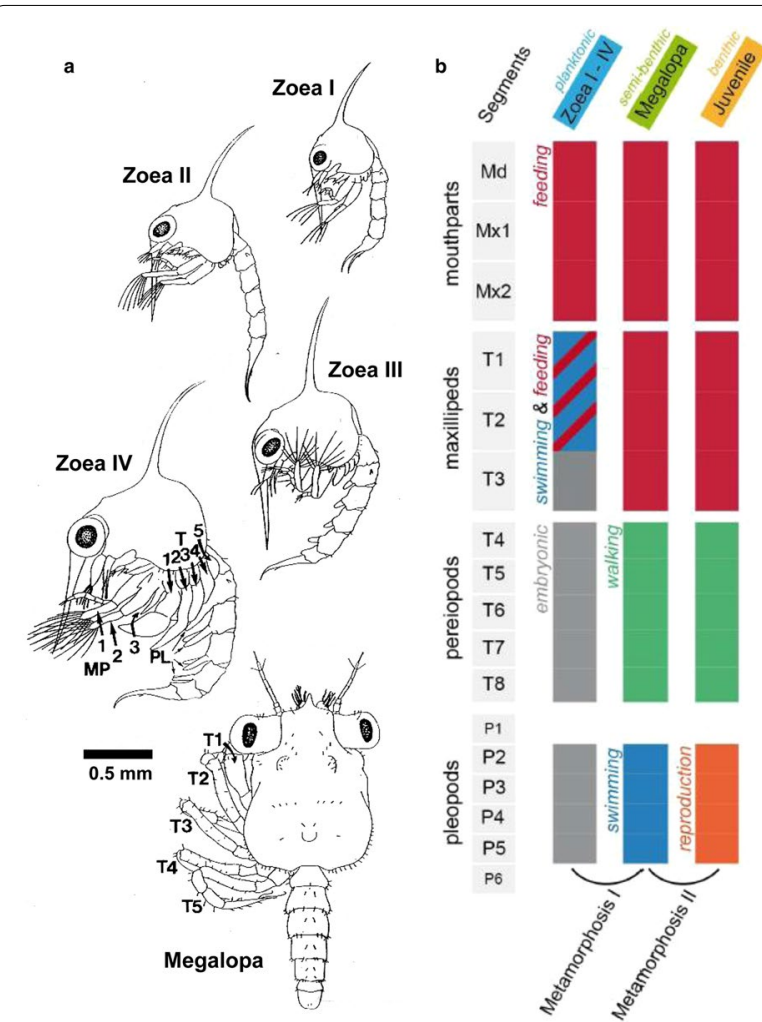

Fig. 2 Larval development of the European shore crab Carcinus maenas L. (Decapoda, Brachyura, Portunidae). a The transition between the zoeal stages and metamorphosis I to Megalopa are characterized by moults (modified from [233]). b Ontogenetic change of appendage function during the double metamorphosis (see text for further details; from [35]). Md: mandibular segment, Mx1, Mx2: segments of 1st and 2nd maxilla; MP 1-3: maxillipeds 1-3 (corresponding to thoracomeres 1-3); P1-5: pereiopod one to five (corresponding to thoracomeres 4-8); PM1-6: pleomeres one to six; T1-8: thoracomeres one to eight

successive moults through a species-dependent number of larval instars that can be variable depending on environmental conditions (reviews $[15,21,22]$ ). In the absence of parental care, larvae need to be adapted to developing in the plankton and such morphological and behavioural adaptations are related to movement, nutrition, and sensing (reviews [10, 11]). In some decapod groups, after a metamorphic moult (review [23]) the larvae eventually settle to the benthos (review [24-26]) where juvenile growth into adulthood, reproduction, embryonic development, and larval hatching occurs (Figs. 1, 2).

The larval forms can differ drastically from their corresponding juvenile-adult stages in morphology, ecology, and behaviour (Fig. 1a, b). In the past, this has caused quite some trouble to identify larval forms as such and many of them have originally been described as separate new species. Many modern-day names for larvae refer to such names (e.g. [12]). To ontogenetically bridge the strong differences between larvae and later stages, many decapod crustaceans undergo a drastic metamorphosis during post-embryonic development (Fig. 2a; reviews $[12,16,23])$.

Decapod larvae are fascinating models to study a broad variety of biological processes, some of which we will point out in this contribution. For example, decapod larvae have attracted the attention of ethologists because they display a rich behavioural repertoire that allows studying responses to variations in environmental drivers such as light, hydrostatic pressure, tidal currents, temperature, salinity, and food concentration (reviews [11, 19, 25, 27-29]). The larval sensory systems include compound eyes as well as abundant chemo- and mechanosensory sensilla [30-35] for instance to perceive chemical cues from their conspecifics to identify suitable habitats to metamorphose and recruit (reviews [19, 26, 27, 29]). Circatidal behavioural patterns, such as active vertical migration in response to tidal currents, allow the larvae to avoid predators and to control their horizontal dispersal (reviews $[4,17,28,36]$ ).

Like many marine animals, a large number of decapods develop through dispersing pelagic larvae that drive the gene flow that connects established populations and hence are important for population structure and population persistence. Furthermore, dispersing larvae play a central role in founding new populations and in species' range expansion (reviews e.g. [18, 37-41]). In species with complex life cycles characterised by habitat shifts, population persistence depends on individuals adapting to environmental changes occurring in both the larval and the adult habitats. Because failure to adapt to only one of such habitats will result in population collapse, either through reproductive or recruitment failure, decapod larvae are well-suited models to study the influence of environmental drivers on species persistence. Furthermore, we now know that larvae represent the life history phase that is highly sensitive to fluctuations of environmental parameters (e.g. [42-45]; reviews [21, 46]). Also, larval development in crustaceans encompasses risks due to higher vulnerability through predation or overdrift into unsuitable habitats for settlement ([37, 47]). Because e.g. temperature controls the dispersal potential through changes in the length of the dispersal phase (and effects on larval growth and survival), quantifying larval responses to variations in environmental drivers ("reaction norms") such as temperature, $\mathrm{pH}$, salinity or food availability can provide new insights into crustacean life-history cycles (reviews [7, 11, 19]). There is a long tradition of examining the reaction norms of decapod crustacean larvae to changes in single or multiple 
environmental drivers which have enriched our understanding of marine larval biology including aspects of supply-side ecology, biogeography, population connectivity, and invasion biology (reviews e.g. [11, 21, 22, 41, 46, 48]).

Analyses of decapod crustacean larvae and their development have also provided new insights into diverse aspects of animal ecophysiology such as phenotypic plasticity in developmental traits, heterochrony in developmental patterns, carry-over effects on life-history traits, and adaptive mechanisms that enhance tolerance to fluctuations in environmental abiotic and biotic factors (reviews e.g. [11, 21, 46, 49, 50]. What is more, crustacean larvae have served as distinguished models in the field of Ecological Developmental Biology or "EcoDevo" for many decades. EcoDevo examines how developmental mechanisms and their resulting phenotype depend on an environmental context as seen in "real-world environments" and explores how developmental pathways incorporate environmental cues to generate contextdependent phenotypes including resulting fitness differences [51-53]. "Environment" in the EcoDevo-context includes abiotic and biotic factors (e.g. temperature, food, conspecifics, predators), but also endocrine disruptors (i.e. environmental compounds that can disrupt normal development by changing gene expression) and teratogens (i.e. compounds causing birth defects) modifying normal development [51-53]. A contemporary line of research in the field of EcoDevo aims at gaining insights into the immediate tolerance of organisms and their evolutionary potential to adapt to the changing physical and biotic environmental conditions created by anthropogenic climate change $[54,55]$. Phenotypic plasticity and evolutionary adaptation are currently discussed as essential mechanisms for organisms to adapt to environmental change in marine ecosystems $[56,57]$. Such processes ultimately will determine which species will adapt to climate change so that an EcoDevo perspective may be critical to understand and predict the future of organisms in a changing world [54]. More and more, understanding synergism and antagonism among multiple environmental drivers is recognized as essential to predict future species distribution [57-59] and decapod larvae are well suited to analyse such effects of combined multiple drivers (e.g. [42, 44, 45]).

Cells, tissues, and organs are at the basis of all biological processes outlined above. Already at hatching, decapod crustacean larvae possess a wealth of organ systems, many of which also characterise the adult animals, necessary for autonomously surviving and developing in the plankton and suited to respond adaptively to fluctuations of environmental drivers. These include for example a sophisticated digestive system, osmoregulatory and respiratory organs, a well-developed neuromuscular system, and a range of sensory organs to detect environmental cues (Table 1). As the larvae develop, their organs continue to grow in size and complexity. The digestive system adapts to changes in the larval food spectrum and energetic demands as the animals grow. The central nervous system integrates new input from sensory organs on the enlarging body surface and generates adaptive behaviours as the larvae of benthic species change from life in the water column to life on the ocean floor. The respiratory and excretory organs adapt to increasing physiological demands as the animals increase their body size and metabolism. Table 1 summarises previous studies on organogenesis in reptantian crustaceans. To study organ development, researchers need a set of state-of-the-art methods, appropriate for the different demands of the different structures and for the usually very small size of the larvae. Furthermore, for descriptions of larval morphology, which is one major field of crustacean research with a very long tradition [12, 60-62], techniques for larval culture, and fixation and preparation of specimens are necessary. This review sets out to provide an overview of such methods to study the morphology and organogenesis in decapod larvae. This first section focuses on larval rearing, preparation, and fixation whereas the companion paper [63] describes the cytological and histological methods in more detail.

\section{Obtaining and handling larvae Introduction}

The study of larval development and physiology (methods described in the following sections) requires the use of appropriate rearing techniques in order to reach the desired stage in sufficient numbers for a meaningful sample (Fig. 3). Furthermore, the chosen larval stages have to be correctly sampled to allow for further processing and analysis (see sampling techniques in the following sections). Here, we give a brief overview of methods for rearing decapod larvae, with emphasis on those developed and tested in the laboratory led by Klaus Anger ([64]) for nearly 40 years (see $[10,16,19,65,66])$ at the Biologische Anstalt Helgoland (Alfred-Wegener-Institut, Helmholtz-Zentrum für Polar- und Meeresforschung). Most of Klaus Anger's former students, including ourselves, have adopted these methods and continue to improve them [42, 45, 67-71]. Details of rearing methods have been extensively reviewed over the past 50 years [72-78] mostly for aquaculture. In this review, we focus on larval rearing for experimentation, and hence do not cover mass-rearing for aquaculture production. At the experimental level, we cover aspects of the execution (i.e. larval rearing); yet, many aspects of the experimental design depend on the question asked by the researcher and 
Table 1 Examples for studies on late embryonic and larval organogenesis in representatives of Decapoda and other selected Malacostraca including methodological approaches

\section{General external morphology}

Compendia with line drawings based on LiMi

Hippolyte inermis

Carcinus maenas

Portunus acuminatus

Xantho poressa, Xantho pilipes

Gnathophyllum elegans

Periclimenes amethysteus

Several Anomura

Several Stomatopoda

Several Polychelida

Hippidae

\section{General anatomy}

Hippolyte inermis

Cancer anthonyi

Portunus trituberculatus

Carcinus maenas

Maja brachydactyla

\section{Mouthparts and digestive tract}

Several Anomura

Maja brachydactyla

Hyas araneus

Scylla olivacea

Scylla serrata

Ucides cordatus

Dyspanopeus sayi

Sesarma curacaoense

Several Brachyura

Ranina ranina

Menippe mercenaria

Paralithodes camtschaticus

Homarus americanus

Astacus astacus, Procambarus fallax $\mathrm{f}$. virginalis

Jasus edwardsii

Macrobrachium amazonicum

Palaemon elegans

Lysmata amboinensis

Porcellio scaber

\section{Osmoregulatory epithelia}

Carcinus maenas

Eriocheir sinensis

Callianassa jamaicense

Astacus leptodactylus

Several Brachyura and Anomala

Homarus americanus

Palaemontes argentinus

Litopenaeus stylirostris
$[12,60-62]$

clsm, SEM [108]

$\mu C T, 3 D$ [35]

SEM [32]

SEM [109]

SEM [110]

SEM [111]

EF, LiMi [112]

EF [113]

EF [114]

EF [115]

clsm, SEM [108]

$\mathrm{PH}$ [116]

$\mathrm{PH}$ [117]

$\mu C T, 3 D$ [35]

$\mu C T, 3 D$ [92]

EF, LiMi [112]

$\mu C T$, PH, SEM, TEM $[118,119]$

STH, TEM $[84,120]$

$\mathrm{PH}$ [121]

$\mathrm{PH}$ [122-124]

$\mathrm{PH}$ [125]

SEM, LiMi [126]

$\mathrm{PH}$ [127]

SEM [128]

$\mathrm{PH}$ [129]

SEM [130]

$\mathrm{PH}$ [131]

TEM, SEM, STH $[97,130,132]$

SEM, TEM, PH $[133,134]$

SEM [135]

SEM [136]

SEM, TEM $[34,136]$

$\mathrm{PH}, \mathrm{SEM}[137]$

STH, SEM, TEM [138]

IHC, SEM [139], LiMi [140]

IHC [141]

TEM [142]

IHC, PP, SEM [143]

LiMi [140]

IHC, TEM [144]

IHC, PH $[145,146]$

IHC, STH [147]
Table 1 (continued)

\begin{tabular}{ll}
\hline $\begin{array}{l}\text { Crangon crangon } \\
\text { Antennal glands }\end{array}$ & IHC, SEM, STH [148] \\
Astacus leptodactylus & SEM, TEM, IHC [149, 150] \\
Homarus gammarus & IHC [151] \\
Macrobrachium amazonicum & IHC, PP $[152,153]$ \\
Palaemontes argentinus & IHC, PP $[146]$
\end{tabular}

\section{Integument and tegumental glands}

Hyas araneus

STH [120]

Sesarma haematocheir

TEM [154]

Multiple species

STH, TEM [155]

\section{Y organ}

Cancer anthony

STH [156]

Hyas araneus

STH [120]

Muscle

Several decapod species

IHC [157]

Homarus americanus

IHC [158]

Idothea báltica

IHC [159]

Sensory dorsal organ

Several decapod species

SEM [160]

Eyestalk neuroendocrine centres

Cancer anthonyi

STH [156]

Homarus gammarus

STH, IHC [161, 162]

Compound eyes

Several species

Carcinus maenas

Hemigrapsus sanguineus

Rhithropanopeus harrisii

Various Anomala

Panulirus longipes

Procambarus clarkii

Alima pacifica

\section{Aesthetascs}

Carcinus maenas

Cherax destructor

\section{Structure of the larval CNS and neurogenesis}

Carcinus maenas

STH, PM, TEM $[163,164]$

STH, PM [30]

STH [165]

STH [165]

STH [166]

TEM [167]

STH, TEM [168]

3D, osmium-ethyl gallate staining [169]

SEM, TEM [170]

SEM, LiMi [171]

Embryonic neurogenesis was recently reviewed [172-174] and will not be considered here

STH, $\mu C T, 3 D, I H C$ [175-178]

IHC, PM, STH [179-183]

STH, 3D [184]

STH, 3D [184]

PM $[171,185,186]$

STH, PM, IHC [183, 186-192]

STH, TEM, IHC [161, 162]

STH, 3D [184]

clsm: confocal laser-scan microscopy; EF: epifluorescence, IHC:

immunohistochemistry; LiMi: light microscopy of external morphology; $\mu \mathrm{CT}$ :

X-ray microscopy; PH: paraffin histology; PM: proliferation markers; SEM:

scanning electron microscopy; STH: semithin histology; TEM: transmission

electron microscopy; 3D: 3D reconstruction 

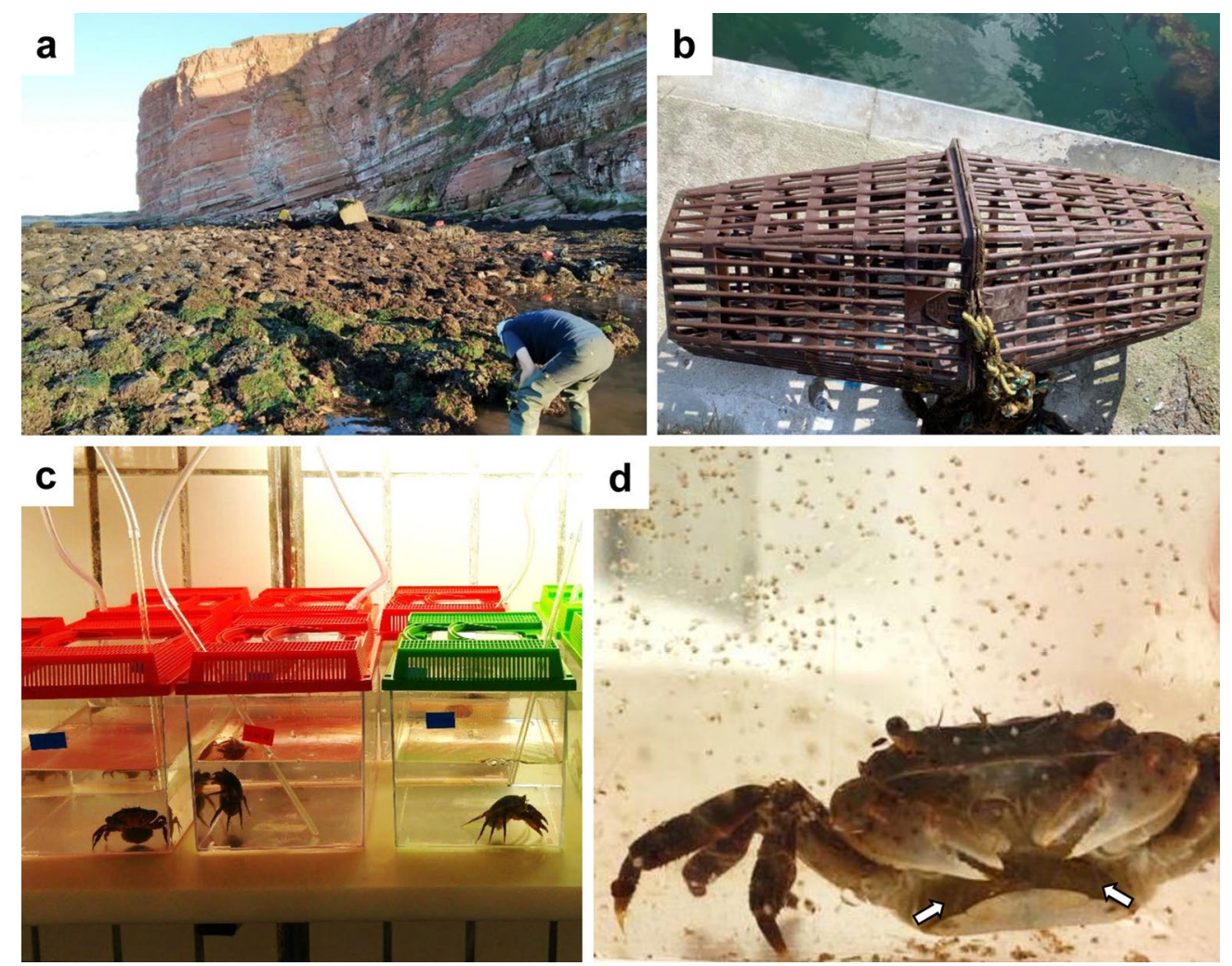

Fig. 3 Collection and maintenance of berried crab females. a Collecting berried females in the rocky intertidal of the island Helgoland (German Bight, North Sea; photo S. Harzsch). b Baited traps (photo G. Torres). c Individual rearing of berried females (Carcinus maenas) prior to hatching (photo Z. Šargač). d Hemigrapsus sanguineus, berried female releasing larvae (photo N. Espinosa). Arrows in d point to the eggs with embryos being carried by berried females

should follow standard procedures of sampling theory. We refer to key references for the extensive discussion of experimental design [79-81]. Instead, we emphasise four cornerstone elements that are essential to larval rearing: who?, how?, where? and how long? Finally, yet importantly, the most essential rule: be patient (additional comments).

\section{Description of methods Who? "Each species is a different world"}

Finding out how to rear the larvae of a "new species" (i.e. newly hosted in the lab) requires a series of preliminary experiments, the output (a meaningful result) is an optimal rearing method for the larvae in question. Literature research focussed on rearing methods for early stages (i.e. larvae) of the target or a similar species (see Table 2 for examples) is the starting point to develop a new method. In addition, such literature research is invaluable for exceptional cases (e.g. for the morphological description of a new species), when only one berried female (i.e. female carrying eggs with embryos, see arrows in Fig. 3c, d) is available. In this situation, careful consideration of the embryos' size and the amount of reserves in the embryos may point to the size and nutritional requirements of the first larval stage. For instance, large embryos will develop into large larvae, lecithotrophic larvae can be expected from embryos with a high amount of reserves (e.g. Sesarma meridies [82]; while small embryos with low reserve amounts will likely produce planktotrophic larvae (e.g. Cancer pagurus [83]. The methods used to rear larvae vary considerably among species, according to the size, shape, presence of spines, and the environmental conditions required for optimal survival (e.g. temperature, salinity, dissolved $\mathrm{O}_{2}$, food availability, among others). For instance, species with long spines may require larger containers and gentle (or no permanent) bubbling as compared with species with short spines. Species with slow swimming larvae may need stronger aeration. Species producing relatively large larvae ( $>10 \mu \mathrm{g}$ dry mass) may be reared using Artemia sp. nauplii as the only food source, but those producing smaller larvae may require additional (or other) food sources (e.g. rotifers, microalgae). Some species are quite suitable for rearing and 
have been adopted as models (Hyas araneus: [65, 8487]); there are other species where success is only partial (Cancer pagurus: [83]).

The optimization of rearing methods is not only about trying different types of containers or environmental conditions. In order to find out what the larvae are doing inside the rearing containers and to obtain critical information, long periods of observation are essential. For instance: if larvae are cannibalistic, individual rearing is mandatory; if they interfere with each other while swimming, a lower density is vital and gentle aeration (or no aeration) is a must. If they are physically damaged by the walls or any other structure placed inside the container, another type of container is required; if they try to feed but cannot capture prey, or if they do not try to feed, another diet is needed. Furthermore, how larvae respond to light or aeration determines how to regulate the light cycle and light intensity, or strength of air bubbles.

\section{How will the culture proceed?}

There are two potential sources of larvae: either they are directly collected in the field ("wild" larvae) or they are obtained from berried females collected in the field and kept in the laboratory until hatching. Here, we focus on methods based on larvae obtained from berried females. For "wild" larvae (i.e. collected in the field), the rearing methods described here also apply as long as the species is known and specimens are handled with great care during collection (e.g. avoid individuals being entangled with the mesh of a plankton net). If the species is unknown, observations on morphology and size may help to infer the optimal rearing methods (see below).

The first step in the successful rearing of larvae is the collection and maintenance of healthy berried females. Each species will require specific collection methods (see literature cited in Table 2) depending on the habitat: for instance, the use of a dredge (e.g. Hyas araneus [65]) or baited traps (e.g. Carcinus maenas and Homarus gammarus [88], Fig. 3) for subtidal species, careful hand collection for intertidal and semi-terrestrial species (Carcinus maenas [44], Metopaulias depressus [89], Fig. 3). Besides, it is essential to consider the temporal range of the reproductive period, when the berried females are available. The timing of collection, considering the length of embryogenesis, will be essential for the aims of the study: i.e. early embryos will allow for manipulation during the embryonic development [45], while late embryos will minimise the acclimation to the laboratory conditions [42]. Furthermore, while the berried females are being transported, a high-quality environment is critical; this includes a constant temperature similar to the collection habitat, enough ambient humidity or access to sufficient water, $\mathrm{O}_{2}$ availability, and adequate space per individual. The maintenance of the females in the laboratory must ensure that females are in an environment similar to the natural habitat (e.g. access to dry periods for intertidal species, optimal temperature, dark:light periods, access to food, Fig. 3). In addition, unnecessary manipulation should be avoided in order to minimise stressing the animals. Water quality is of utmost importance (see next section): some species will need a flow-through system, where water is renewed constantly (e.g. Homarus gammarus [90]; others may be kept in aquaria in still water with periodic water changes (e.g. Armases miersii [91]. In a flow through system, an appropriate collection system must be in place, where the larvae are gently gathered in a sieve located in the outflow of the aquaria. In aquaria, the water quality at hatching will determine a successful larval rearing; thus, it is important to provide enough water volume in the aquaria to ensure relatively low densities of the newly hatched larvae (see Fig. 3e, d).

To ensure a maximum of health, thus high survival, larvae have to be handled with much care and reared in a high-quality habitat, mimicking the natural environment as much as possible. In general, larvae are very sensitive to manipulation (e.g. water changes) and therefore, it is essential to be gentle. For most species, and in particular, for stages with large spines, pipetting (using wide-bore glass pipettes) each individual is better than using a sieve when transferring larvae from one container to a new clean one. Nevertheless, when larvae are more robust, sieving could be useful to save time in mass-rearing cultures (see below). To obtain abundant survivors, the best possible environment (regardless of experimental treatments) is an essential requisite, thus the highest water quality and high hygiene standards (e.g. researcher, rearing room, equipment) are key.

Water quality The water quality is critical to complete successfully the larval development. Thus, natural water, originating from an unpolluted source and with a low nutrient charge, should be treated with UV-light and filtered $(0.2-1 \mu \mathrm{m}$ filter) before use to avoid contamination with other small organisms (in some cases, even autoclaved). Moreover, the researcher has to consider also other abiotic (i.e. $\mathrm{O}_{2}$ concentration, light, temperature, $\mathrm{pH}$, etc.) and biotic variables (e.g. absence of other organisms, food quality, and concentration, etc.). The concentration of dissolved $\mathrm{O}_{2}$ is essential, as it will provide the necessary $\mathrm{O}_{2}$ required for respiration, but also prevent a decrease in $\mathrm{pH}$. Ambient light is crucial to ensure development. Different species may have different requirements of e.g. photoperiod and light intensity (e.g. [92]). Most organisms have a range of temperatures where they are able to develop (e.g. [42, 43, 83, 84, 93]). Some lar- 
Table 2 A non-exhaustive table of species and references to larval rearing methods in decapod crustaceans

\begin{tabular}{|c|c|c|}
\hline Group & Species & References \\
\hline \multirow[t]{3}{*}{ Lobsters } & Homarus americanus & [99] \\
\hline & Homarus gammarus & {$[85,90]$} \\
\hline & Nephrops norvegicus & [193] \\
\hline \multirow[t]{11}{*}{ Caridean shrimps } & Crangon crangon & [194] \\
\hline & Crangon allmanni & [194] \\
\hline & Campylonotus vagans & [195] \\
\hline & Macrobrachium amazonicum & [196] \\
\hline & Macrobrachium pantanalense & [153] \\
\hline & Palaemon spp. & {$[197,198]$} \\
\hline & Palaemon argentinus & [199] \\
\hline & Palaemon serratus & {$[200]$} \\
\hline & Palaemon varians & [201] \\
\hline & Palaemonetes zariquieyi & {$[68]$} \\
\hline & Pandalus montagui & [202] \\
\hline \multirow[t]{6}{*}{ Anomuran crabs } & Galathea squamifera & {$[85]$} \\
\hline & Galathea intermedia & [203] \\
\hline & Lithodes maja & [204] \\
\hline & Lithodes santolla & {$[67]$} \\
\hline & Pagurus bernhardus & [205] \\
\hline & Paralomis granulosa & [67] \\
\hline \multirow[t]{13}{*}{ Brachyuran crabs } & Armases angustipes & [206] \\
\hline & Armases miersii & [91] \\
\hline & Armases roberti & {$[66]$} \\
\hline & Armases ricordi & [207] \\
\hline & Cancer pagurus & {$[83,85]$} \\
\hline & Carcinus maenas & {$[44,85]$} \\
\hline & Cardisoma armatum & [208] \\
\hline & Chiromantes eulimene & [209] \\
\hline & Chiromantes ortmanni & [210] \\
\hline & Cyrtograpsus affinis & [211] \\
\hline & Eriocheir sinensis & {$[93,212]$} \\
\hline & Geograpsus lividus & [213] \\
\hline & Hemigrapsus sanguineus & [43] \\
\hline \multirow[t]{15}{*}{ Brachyuran crabs } & Hexapanopeus schmitti & [214] \\
\hline & Hyas araneus & {$[65]$} \\
\hline & Hyas coarctatus & {$[215]$} \\
\hline & Inachus dorsettensis & [216] \\
\hline & Libinia emarginata & [217] \\
\hline & Libinia ferreirae & [218] \\
\hline & Liocarcinus holsatus & {$[219,220]$} \\
\hline & Macropodia rostrata & [202] \\
\hline & Maja brachydactyla & [221] \\
\hline & Maja squinado & [202] \\
\hline & Menippe mercenaria & [217] \\
\hline & Metasesarma rubripes & [222] \\
\hline & Metopaulias depressus & [89] \\
\hline & Necorapuber & {$[202]$} \\
\hline & Neohelice granulata & [223] \\
\hline
\end{tabular}

Table 2 (continued)

\begin{tabular}{lll}
\hline Group & References \\
\hline Neopanope sayi & {$[217]$} \\
Panopeus austrobesus & {$[224]$} \\
Panopeus herbstii & {$[217]$} \\
Perisesarma fasciatum & {$[225]$} \\
Petrolisthes laevigatus & {$[226]$} \\
Petrolisthes violaceus & {$[227]$} \\
Pilumnus hirtellus & {$[85]$} \\
Pinnotheres pisum & {$[85]$} \\
Rhithropanopeus harrisii & {$[217]$} \\
Sesarma curacaoense & {$[228]$} \\
Sesarma cinereum & {$[217]$} \\
Sesarma dolpinum & {$[229]$} \\
Sesarma fossarum & {$[230]$} \\
Sesarma meridies & {$[82]$} \\
Sesarma windsor & {$[229]$} \\
Sesarma rectum & {$[231]$} \\
Uca thayeri & {$[232]$}
\end{tabular}

vae are lecithotrophic (i.e. they develop with the reserves invested by the mother); others need prey. There are many aspects to consider when choosing the food. For instance, the type of food will depend on whether the larvae are carnivores, herbivores, or omnivores; prey size has to be adequate to the predator's size (i.e. slightly smaller). Also, the appropriate food concentration must be considered.

To achieve the above-mentioned high water quality, water in the cultures has to be renewed on a daily basis. The main issue is finding a balance between the time invested in the daily water change and the stress caused by manipulating the sensitive larvae. The use of widebore glass pipettes (Fig. 4c) causes less stress during manipulation, thus it should be preferred for sensitive larvae (e.g. with long spines). When using a wide-bore glass pipette, the pipette has to be wide enough to avoid damage to the larval spines. The disadvantage of this approach is that it is time-consuming, so it would be more suitable for individual and group rearing. The use of a sieve (Fig. 4e) can save time when performing mass rearing. Here, the key issue is whether the larvae are sufficiently robust to withstand the stress caused by the sieving. When pouring the culture-water into the sieve larvae must not fall directly onto the mesh. Thus, the sieving equipment (i.e. sieve and collecting vessel, see Fig. 4e) should have the following characteristics: (1) the sieve has to be large enough (e.g. 10-15 cm high, $5-10 \mathrm{~cm}$ diameter; Fig. $\left.4^{\prime \prime}\right)$ while still being manageable (e.g. to be held with one hand). (2) The mesh-size should be significantly smaller than the larval size (to avoid snagging and/or breaking the spines). (3) The 

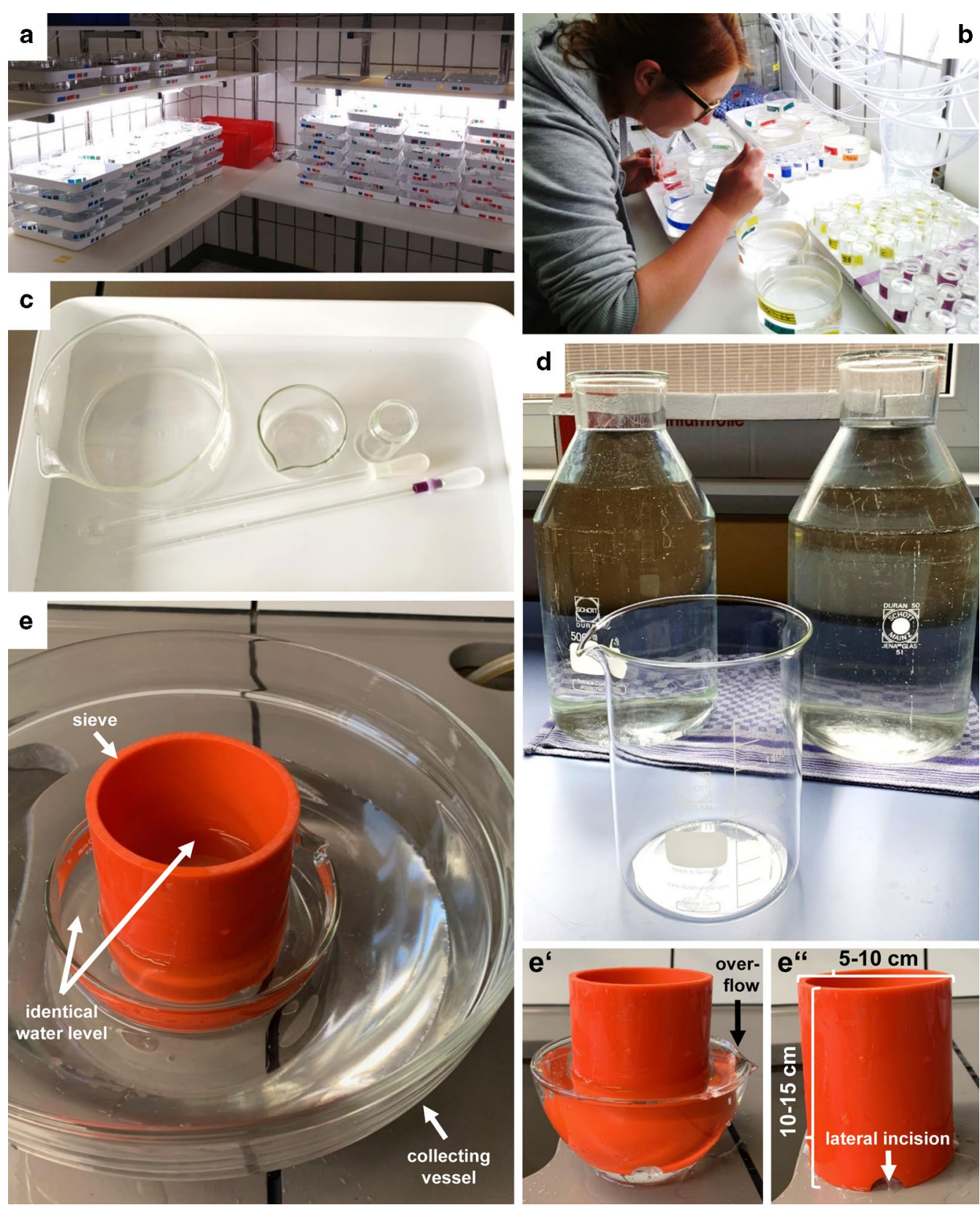

Fig. 4 Obtaining and rearing crab larvae. a Climate-controlled rooms for larval rearing (photo Z. Šargač). b Daily water changes and feeding of larval cultures (photo S. Harzsch). c Rearing containers: $20 \mathrm{ml}$ vials for individual rearing; $60 \mathrm{ml}$ and $500 \mathrm{ml}$ bowls for group rearing (from right to left); wide-bore glass pipettes (photo G. Torres). $\mathbf{d}$ Rearing containers: $2 \mathrm{~L}$ vessels for group rearing; $5 \mathrm{~L}$ bottles for mass-rearing (photo $\mathrm{G}$. Torres). e Sieving equipment. e' Collecting vessel with water overflow. e" Sieve (ca. 10-15 cm high, 5-10 cm diameter) with lateral incisions (photos G. Torres)

sieve should be partly submersed in the collecting vessel (e.g. water level ca. 1-3 cm above the mesh). (4) The collecting vessel should allow overflowing to maintain identical water levels inside and outside the sieve (Fig. 4e, e'). (5) The sieve should have lateral incisions below the mesh to allow drainage of culture-water into the collecting vessel (Fig. 4e"). After pouring the larvae into the sieve, the concentrated larvae can be pipetted out with a wide-bore glass pipette.

Cleanliness The researcher must ensure a high level of personal cleanliness to avoid contamination of the larval cultures (for instance, with food rests, dirt, or any other 
material, or with chemical residues). Rearing rooms (see next section for details) are usually a moist environment that favours mould growth. Therefore, rooms and working surfaces should be dried and cleaned periodically (usually at the end of the day). To avoid contamination with chemicals, it is advisable to keep chemicals (except perhaps ethanol) outside of the rearing room. When rearing occurs in temperature-controlled incubators (see next section) instead, these require special care: they need to be cleaned periodically and checked for ice formation (ideally, there should be a backup incubator in standby to alternate the use/rest and in-depth cleaning/de-icing of the available equipment). The walls of some incubators, as well as other furniture in rearing rooms, may be metallic. When working with seawater, those surfaces must be thoroughly rinsed with freshwater and dried to avoid corrosion due to salt deposits formed on a surface (this is also valid for stainless steel).

Rounded glass containers (vials, bowls, vessels, or bottles) are preferable to rear larvae, as they are dishwasher safe and autoclavable, but many types of plastic containers are usually quite useful as well (Fig. 4). Rearing containers, and any other material, should be cleaned periodically. Depending on species, cleaning may consist of e.g. rinsing containers with hot freshwater during the daily water change. Before transferring the larvae, rearing containers need to be rinsed with seawater, or the appropriate experimental salinity, to avoid changes in salinity due to freshwater residues. Additionally, a weekly thorough cleaning of the container (e.g. scrapping with a brush) may be required. The nature and length of the experiment will determine when containers will need to be dish-washed (with detergent) and/or fully sterilized.

\section{Where? Rearing containers and space}

To control the external experimental conditions of the cultures, especially a pre-determined temperature, larval rearing may be executed in climate-controlled rooms and/or incubators. The former has the advantage to allow for a larger experimental set-up with fewer treatments (ideal for mass-culture; Fig. 4). The latter allows for a smaller experimental set-up but with more treatments in a reduced space (ideal for individual rearing).

Larval rearing methods reflect a balance between the need for high habitat quality and space availability inside the laboratory or incubators. We classify larval rearing in three categories: individual, group, and mass rearing. Individual rearing is the best available method (unless the experiment involves interactions among individuals); however, it demands a high number of containers, increased handling effort (i.e. more time consuming), and usually larger spaces to allocate all the replicate containers (Fig. 4). Individual rearing is usually carried out in small glass vials $(\approx 20-100 \mathrm{ml})$ to optimise space and handling time (Fig. 4c). Group rearing consists of culturing a group of individuals in replicate $100-500 \mathrm{ml}$ bowls (10-50 larvae; Fig. 4c) or 1-3 L vessels (100-200 larvae; Fig. 4d). Finally, mass rearing may be carried out with $100 \mathrm{~s}$ to $1000 \mathrm{~s}$ of larvae in large bottles (>5 L; Fig. 4d). Keeping larval density as low as possible is the critical issue here. Unfortunately, there is no standard rule about the optimal larval density because the consumption of food and oxygen as well as the excretion of e.g. ammonia will depend on the rearing temperature, body mass, and level of activity of the species/stage being reared. Checking literature dealing with larval rearing of a similar species is the starting point to decide the rearing density. When information is not available, preliminary experiments using different rearing densities will provide the optimal density; our "rule of thumb": keep larval density: $10 \mu \mathrm{g}$ dry mass per $10 \mathrm{ml}$ of water. However, we have managed to rear larvae of the European lobster ( $1 \mathrm{mg}$ of dry mass) in $100 \mathrm{ml}$ of water with $80-100 \%$ survival rates, albeit in individual containers [94]. In an optimal situation, aeration is provided by bubbling air into the rearing container, but bubbling may not be possible in many rearing containers. In that case, preliminary experiments should provide information on optimal levels of oxygenation. For optimal rearing, without bubbling, we recommend glasses of a wide surface to volume ratio and daily water changes.

\section{How long will the experiment take place? Beware of the moult cycle!}

In the case of crustaceans, understanding the moult cycle is essential for the appropriate larval rearing; each larval instar consists of a separate moult cycle characterized by rapid developmental changes. A key discovery in the study of the biology of decapod crustacean larvae was that the changes associated with the moult cycle are accompanied by important changes in other physiological variables [82]. Individuals can duplicate their body mass and exhibit important changes in their elemental and biochemical composition, as well as in metabolic rates ([10]); in addition, patterns of tolerance to stressors change within the moult cycle $([66,95,96])$. There are two corollaries from those findings: (1) larval rearing procedures, aimed at quantifying physiological changes, must ensure the tracking of groups of larvae with different moulting histories, and (2) data must be reported with reference to the larval stage and the age within the moult cycle (e.g. [86]).

Tracking groups of larvae, with different moulting histories, requires that individuals moulting on different 
days are monitored closely and kept in separate glasses. Depending on the objective of the experiment, the rearing may start with a single mass culture; as larvae moult to a new stage, the culture is split progressively into new rearing containers after each daily check. This procedure has to be repeated when larvae moult to a subsequent stage. To save space (rearing containers) and handling time (water change of many containers), another option is to split the culture only as soon as the instar of interest is reached.

\section{Additional comments}

\section{Be patient: the longer way is faster and boring is good}

Given the current existing pressure to publish in the scientific community, it is natural to want to develop experiments and produce publishable results as quickly as possible. However, rearing larvae, especially for the first time, requires usually 1-3 months devoted to preliminary experiments, where none of the results produced will be publishable.

The longer way is faster: Culturing a new species demands a series of preliminary experiments aimed to create a protocol for optimal rearing conditions: i.e. optimising the container type (size and shape), level of aeration (bubbling) and larval density required, as well as determining the combination of environmental factors that maximise survival. Furthermore, it is crucial to acquire sufficient manual skills to be able to gently pipette larvae in and out of the different rearing containers as well as identify species and/or specific larval stages. To ensure maximum larval survival, these have to be treated gently, which requires allocating an important amount of time to larval handling (counting of larvae, removal of dead individuals, and determination of moulting stages). Additional time should be allocated to preparing new water, clean the rearing containers, incubators, and rearing room. Within days and/or weeks of practice, the handling time will get shorter and eventually reach an optimum. Skipping the phase of the preliminary experiment has many risks, only justifiable when not many berried females are available. In the long run, rushing in order to "save" time may cause the experiment to fail; hence, going through the long way by running preliminary experiments will allow getting faster to the phase of obtaining reliable results.

Large experiments imply a vast demand in time availability, which requires a change of behaviour in the researchers involved. Many activities performed during the workday (i.e. computer work, breaks, teaching, administration, etc.) have to be arranged around the requirements of larval rearing. In addition, larvae only follow the moult cycle, without any regard to weekends, bank holidays, etc.; they just need their clean water and food when it is due. If a daily water change is missed, it may result in failure of the entire experiment (that may have been running for months). Therefore, a critical point for the researcher is to find the limitations regarding how much time can be allocated to larval rearing per day, to maintain an appropriate balance between work and free time but to ensure obtaining data of quality. Besides, the project leader has to evaluate the needs of each experiment in terms of handling time, in order to allocate the appropriate workforce. As in any other area of experimental sciences, there is a point when it is better not to run an experiment, rather than running a bad one. If the question addressed allows, it is better to stagger a large experiment over a long period (e.g. several months) instead of trying to run many parallel replicates within a short time (e.g. 4-5 weeks). Large experiments demand intensive work over an extensive period: in some sense, as you cage larvae into your rearing containers, they will cage you inside the lab.

Boring is good: Running a large experiment demands patience, as the same work is repeated every day over a long period. In an "uneventful" (standard) day, the researcher gets to the lab, spends long hours checking the experiments, collects data into a table (or collect samples), and goes home; some days are "eventful" because something wrong happens (e.g. food fails, water is not ready to use as it was not prepared in advance, etc.). Usually, it is during the analysis (data or sample analyses) that the researcher will regret making decisions based on impatience and going through the shortcuts. By then the situation is irreversible as the experiment is finished with insufficient individuals for sampling or bad quality data. Instead, a researcher with a patient attitude will enjoy the period of sample and data analysis and appreciate all the time and effort spent in the laboratory.

\section{Conclusion: preliminary experiments are the key to success}

As mentioned above, preliminary experiments are the key to mastering rearing techniques, get self-confidence and ensure high data-quality from the main experiments. It is important to recognise that the time invested in preliminary experiments will not provide data of sufficient quality to warrant a publication, but will ensure a smooth running of the subsequent experiments. In a preliminary experiment, it is advisable to run a smaller version of the full experiment with a couple of repetitions in a temporal sequence. The temporal sequence (instead of parallel runs) enables the researcher to use the previous experience and apply the acquired knowledge to improve the work in the following sequence. Self-confidence is acquired after repetition and the confirmation that results are consistent across experimental runs and also 
are consistent with those obtained in a previous study (if such study is available).

\section{Preparation and fixation Introduction}

In order to ensure tissue preservation, a chemical fixation is the first step in all histological methods that we will describe in the companion paper [63]. The preparation and chemical fixation of the larvae is a key step that defines whether the subsequent histological processing will be successful. Arthropods in general, no matter how small they are, show low permeability to any fixative that has to go through their cuticle. As a rule of thumb, the higher the microscopic detail required, the more important proper fixation becomes. The low permeability of the cuticle delays the penetration of fixatives and thus may reach the organs when they are already in the process of deterioration. Therefore, a preparation that at low microscopic magnification of semi-thin sections seems acceptable may later turn out to be unsuitable to show ultrastructural details under the transmission electron microscope (TEM). In addition, the subsequent infiltration with the reagents needed to process a specimen e.g. for TEM analysis is slowed down by the low permeability of the arthropod cuticle. Note that the overwhelming majority of chemicals and reagents used in histology are highly toxic. Therefore, carefully consider the health and safety regulations in the laboratory (e.g. wear of personal protection equipment, proper storage of chemical fixatives); besides, strictly keep away those chemicals from larval cultures. In the following, we will describe basic aspects of fixation. In the companion paper [63], we will briefly repeat selected aspects of fixation related to the individual techniques described there.

\section{Description of method Dissection}

The two main strategies we recommend to minimize the effects of slow penetration of the fixative are (1) to dissect even small arthropods to make tissue accessible for the fixatives (and other chemicals; [84, 97]), and (2) to use cold to slow down the decay of the tissue (e.g. cold solutions and/or cooling dishes on cold packs). The first step is to anaesthetise the live organisms by chilling (i.e. exposure to a cold environment) until their movement stops. We recommend cooling the larvae for $5 \mathrm{~min}$, immediately dissect them submerged in the fixatives (under a fume hood), and transfer them to a vial with fresh fixative and store them at $4{ }^{\circ} \mathrm{C}$ for at least $24 \mathrm{~h}$. During dissection, the illumination source (from the top, the side or below) and choice of background (black versus transparent) need to be optimised. Furthermore, wellprepared tools are needed (Fig. 5). For example, fine and superfine tip forceps (e.g. Dumont ${ }^{\circledR}$ no. 5-tip dimensions: $0.05 \times 0.01 \mathrm{~mm}$; Dumont ${ }^{\circledR}$ no. 5 superfine, tip dimensions: $0.025 \times 0.005 \mathrm{~mm}$ ) are ideal instruments for dissection. If necessary, the forceps can be sharpened on a fine Arkansas grinding stone in a drop of immersion oil (Fig. 5; squeeze tips of forceps carefully together, grind all sides but the inner ones at a low angle to obtain square tips, then sharpen all four outer corners at an angle of $45^{\circ}$ to obtain trapezoidal tips). By following this procedure, forceps finer than newly bought ones can be obtained. Furthermore, the use of scalpel blades with a rounded blade is useful, but only for a few cuts, because they will get dull quickly. Pieces of razor blades or micro scissors may also do the job. In order to create little perforations on the cuticle, the use of very fine minutiae or pieces of tungsten wire is recommended, without touching the surroundings of the organs of interest. To create the very pointy tips, tungsten wire can be sharpened electrolytically or on sandpaper. Following this procedure, it is possible to obtain an excellent fixation even of specimens that are larger than what is often considered a maximum tissue size (i.e., $1 \mathrm{~mm}^{3}$ ) in textbooks on electron microscopy. Careful preparation will provide an advantage for all the subsequent steps (e.g. infiltration will enhance processes: the penetration of the fixatives, dehydration, and embedding in resin).

We recommend dissecting in glass Petri dishes with SYLGARD $^{\circledR} 184$ Elastomer outfit (black or transparent; or any silicon-based outfit of an elastomer) at the bottom to avoid bending or breaking the extremely sensitive tips of the forceps. At least a few appendages such as spines, limbs, or the pleon (those you do not intend to analyse) should be cut off under a stereo microscope to ensure access of the fixatives (e.g., Hyas araneus [84], Homarus americanus [97]. When cutting off appendages, never do this near the organs that you want to analyse, because they may be mechanically affected. Using minutiae or pieces of very fine tungsten wire to perforate the cuticle will improve fixation even of very small specimens. However, minimise touching the specimens with mechanical devices such as forceps to avoid damage or use tweezers with soft tips. Therefore, it is advisable to leave the specimens within the fixation containers (use small glass vials and not plastic tubes), where they had been transferred to after the dissection. During the subsequent steps, just change the solutions with pipettes without touching the specimens. The preparation should be performed in the cold and all solutions and glassware during the fixation process should be kept cold (e.g. on ice). For the preparation under the stereomicroscope, use a cold pack or Peltier cooling element to keep specimens and slides cold. Make sure not to freeze the specimens as ice crystals may change the integrity of the tissues. 

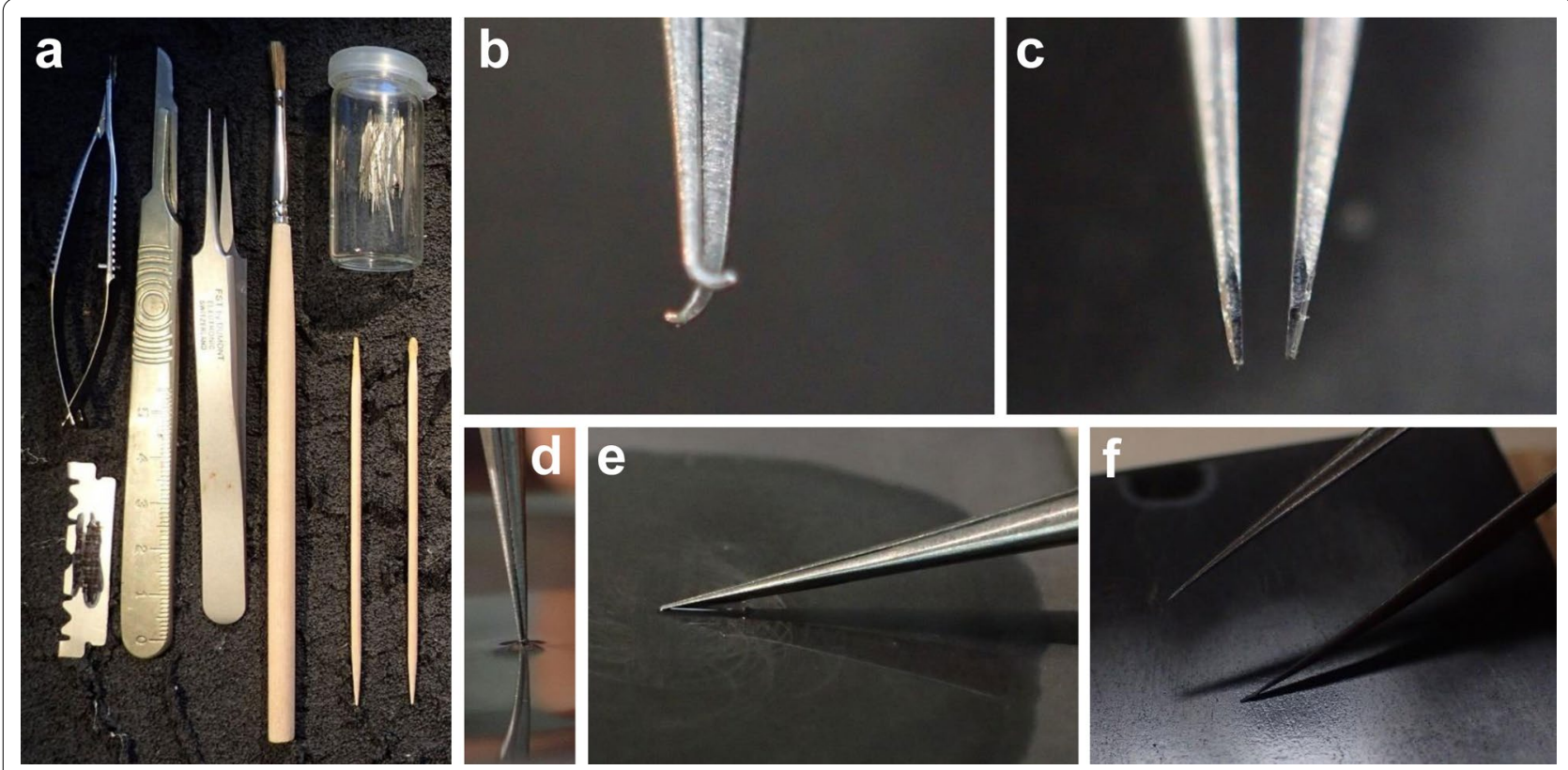

Fig. 5 Helpful tools for microdissection of Zoeae and other minute arthropods (all photos by R. Melzer) a Tools for dissection, mounting, and mechanical cleansing of larvae. Micro scissors, forceps size "5", scalpel, razor blade or small pieces of razor blades, minutiae, tooth sticks with eyelashes glued onto their tips. b-f How to sharpen forceps. b Forceps in a not useful state. c Same forceps as in $\mathbf{b}$, sharpened. $\mathbf{d}$ Sanding the tip to get equal-length arms on extra fine Arkansas grinding stone in oil. e Sharpening of sides of arms. $\mathbf{f}$ Tapering the upper outer edges

\section{Fixation}

During the fixation process, the specimens will be for a long time in vials subjected to various aqueous and nonaqueous solutions. Some tricks that may dramatically improve the results: (a) Specimens should never float on the surface of the fixative; they must be completely submerged in it. To ensure that the specimens are submerged, they may be carefully pushed down with a needle or by carefully squeezing a little plug of cotton wool into the vial. (b) Specimens should not dry out. A couple of drops of the old solution should always be left in the jar before adding the next solution with a pipette. The old solution will be eliminated in the subsequent washing steps. (c) Avoid the transfer of traces of the old solution into the next steps by using a fresh pipette for each step. (d) Eliminate all traces of water before the specimens are transferred to the non-aqueous solutions. A trace of water in the last dehydration steps and/or in the resin will result in badly polymerized resin blocks. (e) Follow the instructions of the manufacturers written on the package leaflets of your reagents.

In Table 3, we have summarized which fixatives in our view are optimal for the various histological methods and list which fixatives may provide acceptable results. Ideally, you have a well-equipped histology lab available to process samples from lab rearing but that may not always be the case. For example, among the available fixatives, the most commonly used for routine plankton fixation is $2-4 \%$ formaldehyde in seawater. However, this mixture is the least suitable for most histological techniques, because it causes shrinkage and various types of deformations. Nevertheless, formaldehyde or paraformaldehyde provide sufficient fixation for many immunohistochemical techniques and subsequent analysis with a fluorescent microscope (Table 3). For example, a typical immunohistochemical protocol requires immersion in 4\% paraformaldehyde (PFA) in PBS (0.1 M phosphate-buffered saline $\mathrm{pH}$ 7.4) for $4 \mathrm{~h}$ at room temperature.

Furthermore, when working with marine organisms in a lab setting and controlled conditions, the osmolarity of the various fixative needs to be adjusted by adding non-electrolytes like sucrose or glucose $[98,99]$ to avoid volume changes of tissue. We recommend adding $2-5 \%$ glucose (or even $9 \%$ ) to adjust the solution osmolarity to that of the larval body fluid. As there are considerable differences between decapod taxa, we suggest starting with $2 \%$ and if necessary, optimise by trying out different concentrations. If you can control fixation in a lab setting, adjusting the osmolarity is a must for all fixatives described below (see also Table 3 ).

If you do not depend on already fixed plankton samples but instead can control fixation yourself in the lab, we recommend using glutardialdehyde instead of formaldehyde and diluting it in phosphate or 
Table 3 Recommended fixatives discriminated by suitability for each specific method

\begin{tabular}{lll}
\hline Histological technique & Recommended fixatives & Acceptable fixatives \\
\hline $\begin{array}{l}\text { External observation: light microscopy and epifluo- } \\
\text { rescence }\end{array}$ & PFA, FASW, Karnovsky's & $75 \%$ ethanol \\
Immunohistochemistry & PFA & FASW \\
Micro CT & Bouin's, PFA & FASW, Karnovsky's, 75\% ethanol \\
Scanning electron microscopy & FAE, AAF & $75 \%$ ethanol \\
Paraffin histology & Bouin's, Karnovsky's & FAE, PFA \\
Semithin sectioning & Bouin's, Karnovsky's or FAE followed by OS & \\
Transmission electron microscopy & Karnovsky's, GA or TA, followed by OS; GAOS & \\
\hline
\end{tabular}

AAF: $85 \mathrm{ml}$ 100\% ethanol, $5 \mathrm{ml}$ glacial acetic acid, $10 \mathrm{ml} 37 \%$ formaldehyde*

Bouin's fixative: $10 \%$ formaldehyde, $5 \%$ glacial acetic acid in saturated aqueous picric acid $1.2 \%$ *

FAE: $150 \mathrm{ml} \mathrm{80 \%} \mathrm{ethanol,} 60 \mathrm{ml} \mathrm{37 \%}$ formalin, and $15 \mathrm{ml}$ glacial acetic acid*

FASW: $4 \%$ formaldehyde in water from the animal's habitat

GA: $4 \%$ glutardialdehyde in $0.1 \mathrm{M}$ phosphate or cacodylate-buffered saline $\mathrm{pH} 7.1-7.3^{*}$

GAOS: $2-4 \%$ glutardialdehyde, $1-2 \% \mathrm{OsO}_{4}$ in $0.1 \mathrm{M}$ cacodylate buffer $\mathrm{pH} 7.1-7.2^{*}$

Karnovsky's solution: 2-4\% formaldehyde and glutaraldehyde in $0.1 \mathrm{M}$ buffer (phosphate buffer or cacodylate buffer) $\mathrm{pH} 7.1$ to $7.2^{*}$

OS: $0.5-4 \%$ osmium tetroxide $\left(\mathrm{OsO}_{4}\right)$ in $0.1 \mathrm{M}$ buffer*

PFA: $4 \%$ paraformaldehyde in $0.1 \mathrm{M}$ phosphate-buffered saline $\mathrm{pH} 7.4^{*}$

TA: $2 \%$ tannin, $2 \%$ glutardialdehyde in $0.1 \mathrm{M}$ sodium cacodylate buffer $\mathrm{pH} 7.2^{*}$

*Adjust osmolarity as described in "Preparation and fixation" section

cacodylate-buffered saline (0.1 M, pH 7.1-7.3) instead of seawater for TEM fixations (Table 3). However, using glutardialdehyde is incompatible with fluorescent probes because it increases the autofluorescence of tissues. For larvae, aqueous fixatives often cause problems for ultrastructural analyses because of the impermeable cuticle even if a dissection was carried out as described above. Most non-aqueous alternatives for scanning electron microscopy (SEM) fixation are ethanol-based, and these fixatives penetrate the tissues much faster than aqueous solutions. Nevertheless, tissue fixation quality is often not good enough, and the larval surface integrity suffers from similar types of artefacts as with water-based fixatives. A long-known fixative well established in paraffin histology and semithin sectioning but also applicable for SEM fixation is alcohol-glacial acetic acid-formalin solution (AAF), a mix of $85 \mathrm{ml} \mathrm{100 \%}$ ethanol, $5 \mathrm{ml}$ glacial acetic acid, and $10 \mathrm{ml} 37 \%$ formaldehyde (Table 3).

For SEM, we have tried different concentrations of ethanol [100] and the best preservation of the larval shape was achieved by using a graded ethanol series (i.e. starting with $30 \%$ ethanol for some minutes, followed by slow dehydration in $50 \%, 60 \%$, and $70 \%$ ethanol), which resulted in excellent fixation of the three-dimensionality of the larvae. For paraffin histology and also semithin sectioning, frequently a formalin-alcohol-glacial acetic acid solution (FAE) is used, a mix of $150 \mathrm{ml} 80 \%$ ethanol, $60 \mathrm{ml} \mathrm{37 \%}$ formalin, and $15 \mathrm{ml}$ glacial acetic acid (Table 3). For these histological methods, also Bouin's fixative is used frequently $(10 \%$ formaldehyde, $5 \%$ glacial acetic acid in saturated aqueous picric acid 1.2\%). For X-ray microscopy, Bouin's solution or $4 \%$ paraformaldehyde (PFA) in phosphatebuffered saline (PBS) or seawater have turned out to be useful fixatives that will also allow immunohistochemical labelling after $\mu$ CT-scanning (Table 3).

For TEM, a more sophisticated chemical fixation using two subsequent steps is typically used. In a first step (the "primary fixative"), tissues are immersed in a buffered aldehyde solution (glutardialdehyde or a formaldehyde/ glutardialdehyde mix) to fix proteins. As the second step ("osmication" or "secondary fixation") tissues are immersed in osmium tetroxide $\left(\mathrm{OsO}_{4}\right)$ in a buffer to fix double bonds, e.g., lipids of cell membranes (reviews in $[101,102])$. A typical TEM primary fixative is Karnovsky's solution, a mix of glutardialdehyde and paraformaldehyde in buffer (Table 3 ). The primary fixative usually contains about 2 to $4 \%$ aldehyde in $0.1 \mathrm{M}$ buffer (Sórensen phosphate buffer or cacodylate buffer) at a slightly alkaline $\mathrm{pH}$ (7.1 to 7.2$)$ and is still done at $4{ }^{\circ} \mathrm{C}$. In most protocols, the secondary fixation (also called "osmication") is carried out after washing the specimens several times for a few minutes in $0.1 \mathrm{M}$ buffer. The final osmium tetroxide concentration $(0.5-4 \%)$ should be present in $0.1 \mathrm{M}$ buffer solution. The incubation times are strongly dependent on the size and infiltration characteristics of the specimens. In very small specimens, 30-60 min of primary fixation is sufficient; fixation time should be prolonged to several hours for larger specimens. In addition, 
washing times in buffers between the primary and secondary fixation may also be modified, depending on size. Afterwards, the specimens are incubated in the secondary fixative for, again, at least half-hour to two hours, or even longer depending on their size. A good indicator of the success of the osmication process during the secondary fixation is an increasing degree of browning/darkening of the specimen's inner parts. After the secondary fixation ("osmication"), the specimens must be washed again in the buffer to remove surplus osmium tetroxide. Specimens fixed according to this double procedure are also well suited for semithin sectioning and subsequent histological stains.

Tanning with tannin and simultaneous fixation with aldehyde and $\mathrm{OsO}_{4}$ can result in excellent fixation (see Table 3). Tanning improves protein fixation and contrast and may allow microtubule subunits to become visible in TEM. To include a tanning step during fixation, prepare a stock solution by diluting ca. $2 \%$ tannin in doubledistilled water for some hours (until it is well dissolved) and filtering through a microfilter. Afterwards, create a primary fixative with $2 \%$ glutardialdehyde $(0.1 \mathrm{M}$ sodium cacodylate buffer, $\mathrm{pH}$ 7.2) solution with $0.5 \%$ tannic acid (modified after [103-106]). Use this solution instead of the primary fixative described above, then wash in the buffer as usual, and afterwards do the secondary fixation (osmication) following the above-mentioned protocol.

A simultaneous fixation with glutaraldehyde and $\mathrm{OsO}_{4}$ is recommended to improve the quality of fixation in small aquatic arthropods [107]. The primary fixative is $2-4 \%$ glutardialdehyde and $1-2 \% \mathrm{OsO}_{4}$ in $0.1 \mathrm{M}$ cacodylate buffer ( $\mathrm{pH}$ 7.1-7.2). This solution has to be mixed immediately before use at $4{ }^{\circ} \mathrm{C}$ to avoid a high percentage of the Osmium being transferred to its tetravalent (pink form) which hinders a good fixation. Afterwards, the specimens should be washed in buffer and are osmicated in the secondary fixative described above.

\section{Additional comments}

For all the histological methods described in the companion paper [63], the most critical step is the preparation and chemical fixation procedure. If the preparation is not adequate for a quick and thorough infiltration of the specimens with the fixatives, the tissues will degrade during the subsequent processing. However, an excessive perforating and/or dissection may mechanically destruct the specimen due to the bad preparation. When larvae are available from laboratory cultures (see "Obtaining and handling larvae" section), it is possible to perform some trials before preparation: e.g. check the best positions for perforating holes, practice the best way of dissection without damaging the target organs, which reagents offer an optimal fixation. In the once-in-a-lifetime catch from the field, however, these preliminary trials will not be possible, and the circumstances may only allow "field" fixation of suboptimal quality.

\section{Animal welfare and ethical issues}

At the time of planning an experiment, it is important to be aware of issues associated to animals' welfare ethics, rules and regulations. Regarding ethical issues, awareness and responsibility is crucial. Due to the experimental conditions, animals may suffer discomfort, experience pain, and/or will be killed. Therefore, the researcher needs to thoroughly consider these issues when starting to plan an experiment, and decide whether to carry experiments with animals (or kill them) at all. The second step is to decide whether the specific experiment is really needed. For the planning of an experiment, there are minimal recommendations regarding the welfare of the animals that will be used. The number of animals included in the experiment or sacrificed should be optimised: sufficient animals should be used to ensure statistically robustness, but avoiding the use of excessive numbers. Both extremes are bad options: while the latter is obviously not desirable at all, too few replicates will lead to low confidence in the results and animals would have died for nothing. In addition, during the experimental procedures, the researcher should aim to be as gentle as possible and provide the best possible environmental conditions to the animals, while still addressing the experimental questions in order to gain the desired new information.

Regarding the legal issues (rules and regulations): there are national and international laws applicable for animals used with scientific purposes, and those are constantly being updated, see for instance: European guidelines on protection of animals used for scientific purposes (DIRECTIVE 2010/63/EU: https://eur-lex.europa.eu/legal-conte nt/EN/TXT/PDF/?uri=CELEX:32010L0063\& from $=$ EN-accessed on the 11th May 2021). It is important to check the rules and regulations concerning killing and experimenting with animals by contacting the animals' welfare officer in the institution where the experiments will take place. The relevant laws and regulations usually give a definition of "animal experiment" and specify how to sacrifice animals among many other topics. Since such regulations depend strongly on the national laws of a country (they may depend on the state within a country), it is not possible to provide information of general standing here. Researchers have to be aware that regulations change frequently: in some countries, such regulations may not cover crustaceans (or their early stages) yet, but this may change in the future. Hence, it is essential to contact the animals' welfare officer well in advance of including experiments involving animals in a project proposal or performing the experiments. This first step will 
ensure that the researcher will be properly instructed on the obligations and legal procedures associated to experiments involving animals. Such instructions may range from the necessity to take courses on welfare of animals used in experimentation, fill application forms to register experiments or request permissions to carry out experiments, to follow any other type of legal procedure associated to working with animals. It should be kept in mind that compliance to ethical and legal issues (e.g. permits) might be needed at the time of the submission of a project proposal or the start of an experiment. There might be a potentially lengthy period from the moment of contact with the animals' welfare officer to the moment when the project proposal can be submitted or the experiment can be started.

\section{Conclusions}

This paper ends with having described all essential steps to rear decapod crustacean larvae from individuals to mass cultures. The companion paper [63] will describe the techniques to study cells, tissues, and organ development in these animals.

\begin{abstract}
Acknowledgements
We dedicate this review to Klaus Anger who introduced us to the incredible world of tiny crustacean larvae with utmost patience. FS, ZS, and SH were supported by the DFG Research Training Group 2010 RESPONSE. We wish to thank Jakob Krieger, Marie Hörnig, Carolin Haug, and Joachim Haug for commenting on a draft version of this paper. We gratefully acknowledge Georg Brenneis for posing in Fig. 3a and FS in Fig. 4b. We are indebted to Noé Espinosa for contributing the figure of a berried female of Hemigrapsus sanguineus releasing larvae (i.e. hatching).
\end{abstract}

\section{Authors' contributions}

GT, RRM, SH and LG conceived and wrote this paper. SH compiled the plates. FS and ZS assisted in writing the paper and contributed images. All authors read and approved the final manuscript.

\section{Funding}

Open Access funding enabled and organized by Projekt DEAL. FS, ZS, and SH were supported by the DFG Research training Group 2010 RESPONSE.

\section{Availability of data and materials}

Not applicable, we do not report any original data here.

\section{Declarations}

\section{Ethics approval and consent to participate}

Not applicable because this technical review does not report any original data and does not describe any original experiments.

\section{Consent for publication}

Not applicable.

\section{Competing interests}

The authors declare that they have no competing interests.

\section{Author details}

${ }^{1}$ Biologische Anstalt Helgoland, Alfred-Wegener-Institut, Helmholtz-Zentrum für Polar-und Meeresforschung, Ostkaje 1118, 27498 Helgoland, Germany.

${ }^{2}$ Bavarian State Collection of Zoology - SNSB, Münchhausenstraße 21,
81247 Munich, Germany. ${ }^{3}$ Department Biologie II, Ludwig-MaximiliansUniversität München, Großhaderner Straße 2, 82152 Planegg-Martinsried, Germany. ${ }^{4}$ GeoBioCenter LMU, Richard-Wagner-Str. 10, 80333 Munich, Germany. ${ }^{5}$ Department of Cytology and Evolutionary Biology, Zoological Institute and Museum, University of Greifswald, Soldmannstrasse 23, 17498 Greifswald, Germany. ${ }^{6}$ School of Ocean Sciences, Bangor University, Askew Street, Menai Bridge LL59 5AB, UK.

Received: 4 October 2020 Accepted: 18 May 2021

Published online: 02 June 2021

\section{References}

1. Schram FR. Comments on crustacean biodiversity and disparity of body plans. In: Watling L, Thiel M, editors. The natural history of the Crustacea, Volume 1: functional morphology \& diversity. Oxford: Oxford University Press; 2013. p. 1-33.

2. Watling $\mathrm{L}$, Thiel $\mathrm{M}$. The role of natural history in understanding of lifestyles in crustaceans. In: Watling L, Thiel M, editors. The natural history of the Crustacea: Volume 2: functional morphology and Diversity. Oxford: Oxford University Press; 2015. p. 1-13.

3. Wellborn GA, Thiel M. The natural history of the Crustacea, Volume 5: life histories. Oxford: Oxford University Press: 2018.

4. Epifanio C. Early life history of the blue crab Callinectes sapidus: a review. J Shellfish Res. 2019;38:1-22.

5. Young AM, Elliott JA. Life history and population dynamics of green crabs Carcinus maenas. Fishes. 2020:5:1-44.

6. Hänfling B, Edwards F, Gherardi F. Invasive alien Crustacea: dispersal, establishment, impact and control. Biocontrol. 2011;56:573-95.

7. Epifanio CE. Invasion biology of the Asian shore crab Hemigrapsus sanguineus: a review. J Exp Mar Bio Ecol. 2013;441:33-49.

8. Leignel V, Stillman JH, Baringou S, Thabet R, Metais I. Overview on the European green crab Carcinus spp. (Portunidae, Decapoda), one of the most famous marine invaders and ecotoxicological models. Environ Sci Pollut Res. 2014;21:9129-44.

9. Gallardo B, Clavero M, Sánchez MI, Vilà M. Global ecological impacts of invasive species in aquatic ecosystems. Glob Change Biol. 2016;22:151-63.

10. Anger K. The biology of decapod Crustacean larvae. 1st ed. Lisse: A.A. Balkema Publishers; 2001.

11. Anger K. Contributions of larval biology to crustacean research: a review. Invertebrate Reproduct Dev. 2006;49:175-205.

12. Martin J, Olesen J, Hoeg J. Atlas of Crustacean larvae. Maryland: JHU Press; 2014.

13. Haug JT, Haug C. "Crustacea": comparative aspects of larval development. In: Wanninger A, editor. Evolutionary developmental biology of invertebrates 4. Vienna: Springer; 2015. p. 63-100.

14. Jirikowski G, Wolff C, Richter S. Evolution of eumalacostracan development-new insights into loss and reacquisition of larval stages revealed by heterochrony analysis. EvoDevo. 2015;6:4.

15. Olesen J. Crustacean life cycles-developmental strategies and environmental adaptations. In: Anger K, Harzsch S, Thiel M, editors. The natural history of the Crustacea Volume 5: life histories. Oxford: Oxford University Press; 2018. p. 1-34

16. Möller OS, Anger K, Guerao G. Patterns of larval development. In: Anger K, Harzsch S, Thiel M, editors. The natural history of the Crustacea Volume 7: developmental biology and larval ecology. Oxford: Oxford University Press; 2020. p. 165-94.

17. Cronin T, Forward RB. Vertical migration cycles of crab larvae and their role in larval dispersal. Bul Mar Sci. 1986;39:192-201.

18. Morgan SG. Dispersal. In: Anger K, Harzsch S, Thiel M, editors. The natural history of the Crustacea Volume 7 : developmental biology and larval ecology. Oxford: Oxford University Press; 2020. p. 383-407.

19. Anger K, Queiroga H, Calado R. Larval development and behaviour strategies in Brachyura. In: Castro P, Davie PJF, Guinot D, Schram FR, von VaupelKlein JC, editors. Treatise on Zoology-Anatomy Taxonomy Biology The Crustacea part C-I, Decapoda: Brachyura, vol. 9. Brill: Leiden; 2015. p. 317-74

20. Jeffs A, O'Rorke R. Feeding and nutrition of Crustacean larvae. In: Anger K, Harzsch S, Thiel M, editors. The natural history of the Crustacea 
Volume 7: developmental biology and larval ecology. Oxford: Oxford University Press; 2020.

21. Giménez L. Phenotypic plasticity and phenotypic links in larval development. In: Anger K, Harzsch S, Thiel M, editors. The natural history of the Crustacea Volume 7: developmental biology and larval ecology. Oxford: Oxford University Press; 2020. p. 284-308.

22. Zeng $C$, Rotllant $G$, Giménez $L$, Romano N. Effects of environmental condition on larval growth and develoment. In: Anger K, Harzsch S, Thiel M, editors. The natural history of the Crustacea Volume 7: developmental biology and larval ecology. Oxford: Oxford University Press; 2020. p. 195-222.

23. Haug JT. Metamorphosis in Crustaceans. In: Anger K, Harzsch S, Thiel M, editors. The natural history of the Crustacea Volume 7: developmental biology and larval ecology. Oxford: Oxford University Press; 2020. p. 254-83.

24. Forward RB, Tankersley RA, Rittschof D. Cues for metamorphosis of Brachyuran Crabs: an overview. Integr Comp Biol. 2001;41:1108-22.

25. Forward RB. Larval biology of the crab Rhithropanopeus harrisii (Gould): a synthesis. Biol Bull. 2009;216:243-56.

26. Gebauer P, Giménez L, Hinojosy I, Paschke K. Settlement and metamorphosis in Barnacles and Decapods. In: Anger K, Harzsch S, Thiel M, editors. The natural history of the Crustacea Volume 7: developmental biology and larval ecology. Oxford: Oxford University Press; 2020. p. 223-53.

27. Forward R, Tankersley RA, Rittschof D. Cues for metamorphosis of Brachyuran crabs: an overview. Am Zool. 2001;41:1108-22.

28. Epifanio $C E$, Cohen JH. Behavioral adaptations in larvae of brachyuran crabs: a review. J Exp Mar Biol Ecol. 2016;482:85-105.

29. Cohen JH, Epifanio CE. Response to visual, chemical, and tactile stimuli. In: Anger K, Harzsch S, Thiel M, editors. The natural history of the Crustacea Volume 7: developmental biology and larval ecology. Oxford: Oxford University Press; 2020. p. 332-59.

30. Harzsch S, Dawirs RR. Maturation of the compound eyes and eyestalk ganglia during larval development of the brachyuran crustaceans Hyas araneus L (Decapoda, Majidae) and Carcinus maenas L. (Decapoda, Portunidae). Zoology. 1995;99:189-204.

31. Garm A. Revising the definition of the crustacean seta and setal classification systems based on examinations of the mouthpart setae of seven species of decapods. Zool J Linnean Soc. 2004;142:233-52.

32. Meyer R, Wehrtmann IS, Melzer RR. Morphology of the first zoeal stage of Portunus acuminatus, Stimpson, 1871 (Decapoda: Portunidae: Portuninae) reared in the laboratory. Sci Mar. 2006;70:261-70.

33. Garm A, Watling L. The crustacean integument: setae, scales, and other ornamentation. In: Thiel M, Watling L, editors. The natural history of the Crustacea Volume 1: functional morphology \& diversity. New York: Oxford University Press; 2013. p. 67-98.

34. Geiselbrecht H, Melzer RR. How do mandibles sense? - The sensory apparatus of larval mandibles in Palaemon elegans Rathke, 1837 (Decapoda, Palaemonidae). Arthropod Struct Dev. 2013;42:1-16.

35. Spitzner F, Meth R, Krüger C, Nischik E, Eiler S, Sombke A, et al. An atlas of larval organogenesis in the European shore crab Carcinus maenas $\mathrm{L}$. (Decapoda, Brachyura, Portunidae). Front Zool. 2018;15:27.

36. Cohen J, Forward RB. Zooplankton diel vertical migration - a review of proximate control. In: Gibson RN, Atkinson RJA, Gordon JDM, editors. Oceanography and marine biology: an annual review. Boca Raton: CRC Press; 2009. p. 77-110.

37. Pechenik JA. On the advantages and disadvantages of larval stages in benthic marine invertebrate life cycles. Mar Ecol Prog Ser. 1999;177:269-97.

38. Cowen R, Gawarkiewicz G, Pineda J, Thorrold S, Werner F. Population connectivity in marine systems: an overview. Oceanog. 2007;20:14-21.

39. Cowen RK, Sponaugle S. Larval dispersal and marine population connectivity. Annu Rev Mar Sci. 2009;1:443-66.

40. Burgess SC, Baskett ML, Grosberg RK, Morgan SG, Strathmann RR. When is dispersal for dispersal? Unifying marine and terrestrial perspectives. Biol Rev. 2016;91:867-82.

41. Moksnes P-O, Jonsson PR. Larval connectivity and marine protected area networks. In: Anger K, Harzsch S, Thiel M, editors. The natural history of the Crustacea Volume 7: developmental biology and larval ecology. Oxford: Oxford University Press; 2020. p. 408-36.
42. Spitzner F, Giménez L, Meth R, Harzsch S, Torres G. Unmasking intraspecific variation in offspring responses to multiple environmental drivers. Mar Biol. 2019;166:112.

43. Giménez L, Exton M, Spitzner F, Meth R, Ecker U, Jungblut S, et al. Exploring larval phenology as predictor for range expansion in an invasive species. Ecography. 2020;43:1-12.

44. Torres G, Giménez L. Temperature modulates compensatory responses to food limitation at metamorphosis in a marine invertebrate. Funct Ecol. 2020;34:1-13.

45. Torres G, Thomas DN, Whiteley NM, Wilcockson D, Giménez L. Maternal and cohort effects modulate offspring responses to multiple stressors. Proc R Soc B: Biol Sci. 2020;287:20200492.

46. Torres G, Spitzner F, Harzsch S, Giménez L. Ecological Developmental Biology and global ocean change: brachyuran crustacean larvae as models. In: Perspectives on evolutionary (and) developmental biology. Padova University Press; 2018. p. 283-306.

47. McEdward L. Ecology of marine invertebrate larvae. Milton Park, Boca Raton: Routledge, CRC Press; 1995.

48. Anger K. Salinity as a key parameter in the larval biology of decapod crustaceans. Invertebrate Reprod Dev. 2003:43:29-45.

49. Charmantier G, Charmantier-Daures M, Towle D. Osmotic and ionic regulation in aquatic arthropods. In: Osmotic and Ionic Regulation. CRC Press; 2009. p. 66.

50. Lignot J, Charmantier G. Osmoregulation and excretion. In: Chang ES, Thiel M, editors. The natural history of Crustacea, Volume 4: Physiology. Oxford: Oxford University Press; 2015. p. 249-85.

51. Gilbert SF, Bosch TCG, Ledón-Rettig C. Eco-Evo-Devo: developmental symbiosis and developmental plasticity as evolutionary agents. Nat Rev Genet. 2015;16:611-22.

52. Gilbert SF. Developmental Plasticity and Developmental Symbiosis: The Return of Eco-Devo. In: Current Topics in Developmental Biology. Elsevier; 2016. p. 415-33.

53. Gilbert SF. Ecological Developmental Biology. In: eLS. American Cancer Society; 2017. p. 1-8.

54. Sultan SE. Development in context: the timely emergence of eco-devo. Trens Ecol Evol. 2007;22:575-82.

55. Sultan SE. Eco-Evo-Devo. In: Nuno de la RosaMüller LG, editor. Evolutionary developmental biology. Cham: Springer; 2017. p. 1-13.

56. Reusch TBH. Climate change in the oceans: evolutionary versus phenotypically plastic responses of marine animals and plants. Evol Appl. 2014;7:104-22.

57. Boyd PW, Collins S, Dupont S, Fabricius K, Gattuso J-P, Havenhand J, et al. Experimental strategies to assess the biological ramifications of multiple drivers of global ocean change-a review. Glob Change Biol. 2018;24:2239-61.

58. Piggott JJ, Townsend CR, Matthaei CD. Reconceptualizing synergism and antagonism among multiple stressors. Ecol Evol. 2015;5:1538-47.

59. Galic N, Sullivan LL, Grimm V, Forbes VE. When things don't add up: quantifying impacts of multiple stressors from individual metabolism to ecosystem processing. Ecol Lett. 2018;21:568-77.

60. Rice A. Crab zoeal morphology and its bearing on the classification of the Brachyura. Trans Zool Soc Lond. 1980;35:271-424.

61. Williamson D. Larval morphology and diversity. In: Abele LG, editor. The biology of Crustacea: 2. Embryology, morphology and genetics. New York: Academic press; 1982. p. 43-110.

62. Ingle R. Larval stages of north-eastern Atlantic crabs: an illustrated key. London: Chapmann and Hall; 1992.

63. Melzer R, Spitzner F, Sargac Z, Hörnig MK, Krieger J, Haug C, et al. Methods to study organogenesis in decapod crustacean larvae II: analysing cells and tissues. Helgoland Mar Res. 2021 (in press).

64. Bauer R, Gimenez L, Storch V. Klaus Anger, recipient of the Crustacean society excellence in research award. J Crustacean Biol. 2015;35:116-9.

65. Anger K, Nair KKC. Laboratory experiments on the larval development of Hyas araneus (Decapoda, Majidae). Helgoländer wiss Meeresuntersuch. 1979;32:36-54.

66. Torres G, Anger K, Giménez L. Effects of reduced salinities on metamorphosis of a freshwater-tolerant sesarmid crab, Armases roberti: Is upstream migration in the megalopa stage constrained by increasing osmotic stress? J Exp Mar Biol Ecol. 2006;338:134-9.

67. Thatje S, Calcagno JA, Lovrich GA, Sartoris F-J, Anger K. Extended hatching periods in the subantarctic lithodid crabs Lithodes santolla and 
Paralomis granulosa (Crustacea: Decapoda: Lithodidae). Helgoland Mar Res. 2003;57:110-3.

68. Urzúa Á, Guerao G, Cuesta JA, Rotllant G, Estévez A, Anger K. The bioenergetic fuel for non-feeding larval development in an endemic palaemonid shrimp from the Iberian Peninsula, Palaemonetes zariquieyi. Mar Freshw Behav Physiol. 2013;46:381-97.

69. Gebauer P, Paschke K, Anger K. Costs of delayed metamorphosis: reduced growth and survival in early juveniles of an estuarine grapsid crab, Chasmagnathus granulata. J Exp Mar Bio Ecol. 1999;238:271-81.

70. Giménez L, Torres G. Larval growth in the estuarine crab Chasmagnathus granulata: the importance of salinity experienced during embryonic development, and the initial larval biomass. Mar Biol. 2002;141:877-85.

71. Paschke KA, Gebauer P, Buchholz F, Anger K. Seasonal variation in starvation resistance of early larval North Sea shrimp, Crangon crangon (Decapoda: Crangonidae). Mar Ecol Prog Ser. 2004;279:183-91.

72. Dawirs RR. Methodological aspects of rearing decapod larvae Pagurus bernhardus (Paguridae) and Carcinus maenas (Portunidae). Helgoländer Meeresuntersuch. 1982;3:439-64.

73. Rice AL, Williamson DI. Methods for rearing larval decapod Crustacea. Helgolander Wiss Meeresuntersuch. 1975;20:417-34.

74. Robertson HM. Culture Techniques for Decapod Crustacean Larvae. In: Culture of Marine Invertebrate Animals: Proceedings 1st Conference on Culture of Marine Invertebrate Animals Greenport. Editors: W. L. Smith and M. H. Chanley. Boston, MA, Springer US; 1975. p. 209-20.

75. Calado R. Decapod Crustaceans. In: Marine Ornamental Species Aquaculture. John Wiley \& Sons, Ltd; 2017. p. 475-6. https://doi.org/10.1002/ 9781119169147.ch22.

76. Calado R, Pimentel T, Vitorino A, Dionísio G, Dinis MT. Technical improvements of a rearing system for the culture of decapod crustacean larvae, with emphasis on marine ornamental species. Aquaculture. 2008:285:264-9

77. Riebesell U, Fabry VJ, Hansson L, Gattuso J-P. Guide to best practices for ocean acidification research and data reporting. Luxembourg: Publications office of the European Union; 2010. https://doi.org/10.2777/66906

78. New MB, Valenti WC, Tidwell JH, D'Abramo LR, Kutty MN. Freshwater prawns: biology and farming |Wiley. Chichester: Wiley-Blackwell; 2010

79. Underwood AJ. Experiments in ecology: their logical design and interpretation using analysis of variance. Cambridge: Cambridge University Press; 1996. https://doi.org/10.1017/CBO9780511806407

80. Hurlbert SH. On misinterpretations of pseudoreplication and related matters: a reply to Oksanen. Oikos. 2004:104:591-7.

81. Quinn G. Experimental design and data analysis for biologists von Gerry P. Quinn - eBook IThalia. Cambidge University Press; 2002.

82. Anger K, Torres G, Nettelmann U. Adaptive traits in ecology, reproduction and early life history of Sesarma meridies, an endemic stream crab from Jamaica. Mar Freshw Res. 2007:58:743-55.

83. Weiss M, Thatje S, Heilmayer O, Anger K, Brey T, Keller M. Influence of temperature on the larval development of the edible crab, Cancer pagurus. J Mar Biol Assoc UK. 2009;89:753-9.

84. Storch V, Anger K. Influence of starvation and feeding on the hepatopancreas of larval Hyas araneus (Decapoda, Majidae). Helgoländer Meeresuntersuch. 1983:36:6775.

85. Anger K. The Do threshold: a critical point in the larval development of decapod crustaceans. J Exp Mar Bio Ecol. 1987;108:15-30.

86. Anger K. Moult cycle and morphogenesis in Hyas araneus larvae (Decapoda, Majidae), reared in the laboratory. Helgoländer Meeresuntersuch. 1983:36:285-302.

87. Anger K. Temperature and the larval development of Hyas araneus $\mathrm{L}$. (Decapoda: Majidae); extrapolation of laboratory data to field conditions. J Exp Mar Bio Ecol. 1983;69:203-15.

88. Torres G, Giménez L, Anger K. Effects of reduced salinity on the biochemical composition (lipid, protein) of zoea 1 decapod crustacean larvae. J Exp Mar Bio Ecol. 2002;277:43-60.

89. Anger K, Schuh M. Bioenergetics of abbreviated larval development in the bromelid crab, Metopaulias depressus (Decapoda: Grapsidae). Comp Biochem Physiol A - Mol Integrat Physiol. 1992;103:507-18.

90. Torres G, Anger K, Giménez L. Effects of short-term and continuous exposure to reduced salinities on the biochemical composition of larval lobster, Homarus gammarus. Zoology. 2021;144:125885.
91. Anger K. Developmental biology of Armases miersii (Grapsidae), a crab breeding in supratidal rock pools. 1. Facultative lecithotrophy of larval stages. Mar Ecol Prog Ser. 1995;117:75-81.

92. Castejón D, Alba-Tercedor J, Rotllant G, Ribes E, Durfort M, Guerao G. Micro-computed tomography and histology to explore internal morphology in decapod larvae. Sci Rep. 2018;8:14399.

93. Anger K. Effects of temperature and salinity on the larval development of the Chinese mitten crab Eriocheir sinensis (Decapoda: Grapsidae). Mar Ecol Prog Ser. 1991;72:103-10.

94. D'Urban Jackson T, Torres G, Gimenez L. Survival and development of larvae of two decapod crustaceans under limited access to prey across a thermal range. J Plankton Res. 2014;36:1476-87.

95. Anger K, Dawirs RR. Influence of starvation on the larval development of Hyas araneus (Decapoda, Majidae). Fish Bull. 1982;80:419-33.

96. Anger K, Spivak E, Luppi T. Effects of reduced salinities on development and bioenergetics of early larval shore crab, Carcinus maenas. J Exp Mar Bio Ecol. 1998;220:287-304.

97. Anger K, Storch V, Anger V, Capuzzo JM. Effects of starvation on moult cycle and hepatopancreas of stage I lobster (Homarus americanus) larvae. Helgoländer Meeresuntersuch. 1985;39:107-16.

98. Bone Q, Ryan KP. Osmolarity of osmium tetroxide and glutaraldehyde fixatives. Histochem J. 1972:4:331-47.

99. Montanaro J, Gruber D, Leisch N. Improved ultrastructure of marine invertebrates using non-toxic buffers. PeerJ. 2016;4:e1860.

100. Meyer R, Melzer RR. Scanning EM diagnosis of marine Decapoda larvae: a comparison of preparation techniques. Crustaceana. 2004;77:883-6.

101. Glauert AM. Fixation, dehydration and embedding of biological specimens. Amsterdam: Elsevier Science; 1984.

102. Hayat MA. Principles and techniques of electron microscopy: biological applications. 4th ed. Cambridge: Cambridge University Press; 2000.

103. Maupin P, Pollard TD. Improved preservation and staining of HeLa cell actin filaments, clathrin-coated membranes, and other cytoplasmic structures by tannic acid-glutaraldehyde-saponin fixation. J Cell Biol. 1983;96:51-62.

104. Dallai R, Afzelius BA. Microtubular diversity in insect spermatozoa: Results obtained with a new fixative. J Struct Biol. 1990;103:164-79.

105. Dallai R, Afzelius BA. Substructure of the axoneme of pterygote insect spermatozoa: phylogenetic considerations. Int J Insect Morphol Embryol. 1993;22:449-58.

106. Nicastro D, Smola U, Melzer RR. The antennal sensilla of the carnivorous "phantom" larva of Chaoborus crystallinus (De Geer) (Diptera, Nematocera). Can J Zool. 1995:73:15-26.

107. Franke WW, Krien S, Brown RM. Simultaneous glutaraldehyde-osmium tetroxide fixation with postosmication. Histochemie. 1969;19:162-4.

108. Zupo V, Buttino I. Larval development of decapod crustaceans investigated by confocal microscopy: an application to Hippolyte inermis (Natantia). Mar Biol. 2001;138:965-73.

109. Melzer R, Friedrich S, Meyer R. Xantho poressa (Olivi, 1792) and Xantho pilipes A. Milne-Edwards, 1867 Larvae (Brachyura, Xanthidae): Scanning Em Diagnosis of Zoea I from the Adriatic Sea. Crustaceana. 2004;77:997-1005.

110. Meyer R, Lehmann T, Melzer RR, Geiselbrecht H. Morphology of the first zoeal stage of the Mediterranean bumblebee shrimp Gnathophyllum elegans studied with both light microscopy and scanning EM. J Mar Biol Assoc UK. 2014:94:151-8.

111. Geiselbrecht H, Melzer RR. Morphology of the first zoeal stage of the partner shrimp Periclimenes amethysteus Risso, 1827 (Decapoda: Caridea: Palaemonidae: Pontoniinae) studied with the Scanning EM. Zootaxa. 2009;2140:45-55.

112. Gundi P, Cecchin C, Fetzer L-L, Haug C, Melzer RR, Haug JT. Giant planktic larvae of anomalan crustaceans and their unusual compound eyes. Helgoland Mar Res. 2020;74:8.

113. Wiethase J, Haug JT, Haug C. Detailed description of some mantis shrimp larvae and their implication for the character evolution within Stomatopoda. Nauplius. 2020;28.

114. Eiler SM, Haug C, Haug JT. Detailed description of a giant polychelidan eryoneicus-type larva with modern imaging techniques. Spixiana. 2016:39:39-60.

115. Rudolf NR, Haug C, Haug JT. Functional morphology of giant mole crab larvae: a possible case of defensive enrollment. Zool Lett. 2016;2:17. 
116. Trask T. Laboratory-reared larvae of Cancer anthonyi (Decapoda: Brachyura) with a brief description of the internal anatomy of the megalopa. Mar Biol. 1974;27:63-74.

117. Nakamura K. Organogenesis during metamorphosis in the swimming crab Portunus trituberculatus. Nippon Suisan Gakk. 1990;56:1561-4.

118. Castejón D, Rotllant G, Ribes E, Durfort M, Guerao G. Foregut morphology and ontogeny of the spider crab Maja brachydactyla (Brachyura, Majoidea, Majidae). J Morphol. 2015;276:1109-22.

119. Castejón $D$, Rotllant $G$, Alba-Tercedor J, Font-i-Furnols M, Ribes E, Durfort M, et al. Morphology and ultrastructure of the midgut gland ("hepatopancreas") during ontogeny in the common spider crab Maja brachydactyla Balss, 1922 (Brachyura, Majidae). Arthropod Struct Dev. 2019:49:137-51

120. Hoecker B. Licht-und elektronenmikroskopische Untersuchungen zur Larval-und Juvenilentwicklung der Seespinne Hyas araneus: Decapoda, Majidae unter besonderer Berücksichtigung des Y-Organs. 1988.

121. Jantrarotai P, Srakaew N, Sawanyatiputi A. Histological study on the development of digestive system in zoeal stages of mud crab (Scylla olivacea). Kasetsart J Nat Sci. 2005;39:666-71.

122. Li F, Li S. Comparative study on the development of gastric mill of the larvae of Scylla serrata. Mar Sci. 1995;5:38-41.

123. Li FH, Li SJ. Studies on the Hepatopancreas of Larval Scylla serrata. Oceanol Limnol Sin. 1998;29:33-8.

124. Lumasag GJ, Quinitio ET, Aguilar RO, Baldevarona RB, Saclauso CA. Ontogeny of feeding apparatus and foregut of mud crab Scylla serrata Forsskål larvae. Aquacult Res. 2007;38:1500-11.

125. Abrunhosa FA, Melo MA, Abrunhosa JP. Development and functional morphology of the foregut of larvae and postlarva of Ucides cordatus (Decapoda, Ocypodidae). Nauplius. 2003;11:37-43.

126. Castejón D, Ribes E, Durfort M, Rotllant G, Guerao G. Foregut morphology and ontogeny of the mud crab Dyspanopeus sayi (Smith 1869) (Decapoda, Brachyura, Panopeidae). Arthropod Struct Dev. 2015:44:33-41.

127. Melo MA, Abrunhosa F, Sampaio I. The morphology of the foregut of larvae and postlarva of Sesarma curacaoense De Man, 1892: a species with facultative lecithotrophy during larval development. Acta Amazon. 2006;36:375-80.

128. Geiselbrecht H, Melzer RR. Mandibles of zoea I larvae of nine decapod species: a scanning EM analysis. Spixiana. 2010;33:27-47.

129. Minagawa M, Takashima F. Developmental changes in larval mouthparts and foregut in the red frog crab, Ranina ranina (Decapoda: Raninidae). Aquaculture. 1994;126:61-71.

130. Factor JR. Development and Metamorphosis of the Digestive System of Larval Lobsters, Homarus americanus (Decapoda: Nephropidae). J Morphol. 1981;169:225-42.

131. Abrunhosa FA, Kittaka J. Functional Morphology of Mouthparts and Foregut of the Last Zoea, Glaucothoe and First Juvenile of the King Crabs Paralithodes camtschaticus, P. brevipes and P. platypus. Fish Sci. 1997;63:923-30.

132. Biesiot PM, MCDowell JE. Midgut-gland development during early lifehistory stages of the American lobster Homarus americanus. J Crustac Biol. 1995;15:679-85.

133. Vogt G. Life-cycle and functional cytology of the hepatopancreatic cells of Astacus astacus (Crustacea, Decapoda). Zoomorphol. 1994;114:83-101.

134. Vogt $G$. Investigation of hatching and early post-embryonic life of freshwater crayfish by in vitro culture, behavioral analysis, and light and electron microscopy. J Morphol. 2008;269:790-811.

135. Nishida S, Quigley BD, Booth JD, Nemoto T, Kittaka J. Comparative morphology of the mouthparts and foregut of the final-stage phyllosoma, puerulus, and postpuerulus of the rock lobster Jasus edwardsi (Decapoda: Palinuridae). J Crustacean Biol. 1990;10:293-305.

136. Batel A, Melzer RR, Anger K, Geiselbrecht H. Heterochrony in mandible development - A comparative SEM study on zoea larvae of two carideans (Decapoda). J Morphol. 2014;275:1258-72.

137. Tziouveli V, Bastos-Gomez G, Bellwood O. Functional morphology of mouthparts and digestive system during larval development of the cleaner shrimp Lysmata amboinensis (de Man, 1888). J Morphol. 2011;272:1080-91.

138. Štrus J, Klepal W, Repina J, Tušek-Žnidarič M, Milatovič M, Pipan Ž. Ultrastructure of the digestive system and the fate of midgut during embryonic development in Porcellio scaber (Crustacea: Isopoda). Arthropod Struct Dev. 2008;37:287-98.

139. Cieluch U, Anger K, Aujoulat F, Buchholz F, Charmantier-Daures M, Charmantier G. Ontogeny of osmoregulatory structures and functions in the green crab Carcinus maenas (Crustacea, Decapoda). J Exp Biol. 2004;207:325-36.

140. Hong SY. Development of epipods and gills in some pagurids and brachyurans. J Nat Hist. 1988;22:1005-40.

141. Cieluch U, Anger K, Charmantier-Daures M, Charmantier G. Osmoregulation and immunolocalization of $\mathrm{Na}+/ \mathrm{K}+$-ATPase during the ontogeny of the mitten crab Eriocheir sinensis (Decapoda, Grapsoidea). Mar Ecol Prog Ser. 2007;329:169-78.

142. Felder JM, Felder DL, Hand SC. Ontogeny of osmoregulation in the estuarine ghost shrimp Callianassa jamaicense var. louisianensis Schmitt (Decapoda, Thalassinidea). J Exp Mar Biol Ecol. 1986;99:91-105.

143. Lignot JH, Susanto GN, Charmantier-Daures M, Charmantier G. Immunolocalization of $\mathrm{Na}+, \mathrm{K}+$-ATPase in the branchial cavity during the early development of the crayfish Astacus leptodactylus (Crustacea, Decapoda). Cell Tissue Res. 2005;319:331-9.

144. Lignot JH, Charmantier G. Immunolocalization of $\mathrm{Na}+$, $\mathrm{K}+$-ATPase in the branchial cavity during the early development of the European lobster Homarus gammarus (Crustacea, Decapoda). J Histochem Cytochem. 2001:49:1013-23.

145. Leone FA, Garçon DP, Lucena MN, Faleiros RO, Azevedo SV, Pinto MR, et al. Gill-specific (Na+, K+)-ATPase activity and a-subunit mRNA expression during low-salinity acclimation of the ornate blue crab Callinectes ornatus (Decapoda, Brachyura). Comp Biochem Physiol B: Biochem Molec Biol. 2015;186:59-67.

146. Ituarte RB, Lignot JH, Charmantier G, Spivak E, Lorin-Nebel C. Immunolocalization and expression of $\mathrm{Na}+/ \mathrm{K}+$-ATPase in embryos, early larval stages and adults of the freshwater shrimp Palaemonetes argentinus (Decapoda, Caridea, Palaemonidae). Cell Tissue Res. 2016;364:527-41.

147. Pham D, Charmantier G, Boulo V, Wabete N, Ansquer D, Dauga C, et al. Ontogeny of osmoregulation in the Pacific blue shrimp, Litopenaeus stylirostris (Decapoda, Penaeidae): Deciphering the role of the $\mathrm{Na}$ + /K + -ATPase. Comp Biochem Physiol B: Biochem Molec Biol. 2016;196-197:27-37.

148. Cieluch U, Charmantier G, Grousset E, Charmantier-Daures M, Anger K. Osmoregulation, immunolocalization of $\mathrm{Na}+/ \mathrm{K}+$-ATPase, and ultrastructure of branchial epithelia in the developing brown shrimp, Crangon crangon(Decapoda, Caridea). Physiol Biochem Zool. 2005:78:1017-25.

149. Khodabandeh S, Charmantier G, Blasco C, Grousset E, CharmantierDaures M. Ontogeny of the antennal glands in the crayfish Astacus leptodacty/us (Crustacea, Decapoda): anatomical and cell differentiation. Cell Tissue Res. 2005;319:153-65.

150. Khodabandeh S, Kutnik M, Aujoulat F, Charmantier G, CharmantierDaures M. Ontogeny of the antennal glands in the crayfish Astacus leptodactylus (Crustacea, Decapoda): immunolocalization of $\mathrm{Na}+$ K+-ATPase. Cell Tissue Res. 2005;319:167-74.

151. Khodabandeh S, Charmantier G, Charmantier-Daures M. Immunolocalization of $\mathrm{Na}+, \mathrm{K}+$-ATPase in osmoregulatory organs during the embryonic and post-embryonic development of the lobster Homarus gammarus. J Crust Biol. 2006;26:515-23.

152. Boudour-Boucheker N, Boulo V, Charmantier-Daures M, Grousset E, Anger K, Charmantier G, et al. Differential distribution of V-type $\mathrm{H}+$-ATPase and $\mathrm{Na}+/ \mathrm{K}+$-ATPase in the branchial chamber of the palaemonid shrimp Macrobrachium amazonicum. Cell Tissue Res. 2014;357:195-206.

153. Boudour-Boucheker N, Boulo V, Charmantier-Daures M, Anger K, Charmantier G, Lorin-Nebel C. Osmoregulation in larvae and juveniles of two recently separated Macrobrachium species: Expression patterns of ion transporter genes. Comp Biochem Physiol A - Mol Integrat Physiol. 2016;195:39-45.

154. Ikeda H, Hirano Y, Saigusa M. A pair of rosette glands in the embryo and zoeal larva of an estuarine crab Sesarma haematocheir, and classification of the tegumental glands in the embryos of other crabs. J Morphol. 2004;259:55-68.

155. Freeman J. The Crustacean Epidermis During Larval Development. In: The Crustacean Integument. Morphology and Biochemistry. Bocan Raton: CRC Press; 1993, 193-219. 
156. McConaugha JR. Identification of the Y-organ in the larval stages of the crab, Cancer anthonyi. Rathbun J Morphol. 1980;164:83-8.

157. Jirikowski GJ, Richter S, Wolff C. Myogenesis of Malacostraca-the "eggnauplius" concept revisited. Front Zool. 2013;10:76.

158. Harzsch S, Kreissl S. Myogenesis in the thoracic limbs of the American lobster. Arthropod Struct Dev. 2010;39:423-35.

159. Kreiss S, Uber A, Harzsch S. Muscle precursor cells in the developing limbs of two isopods (Crustacea, Peracarida): an immunohistochemical study using a novel monoclonal antibody against myosin heavy chain. Dev Genes Evol. 2008;218:253.

160. Lerosey-Aubril R, Meyer R. The sensory dorsal organs of crustaceans. Biol Rev. 2013;88:406-26.

161. Rotllant G, Charmantier-Daures M, Trilles JP, Charmantier G. Ontogeny of the sinus gland and of the organ of Bellonci in larvae and postlarvae of the European lobster Homarus gammarus. Invertebr Reprod Dev. 1994;26:13-22.

162. Rotllant G, Charmantier-Daures M, De Kleijn D, Charmantier G, Van Herp F. Ontogeny of neuroendocrine centres in the eyestalk of Homarus gammarus embryos: an anatomical and hormonal approach. Invertebr Reprod Dev. 1995;27:233-45.

163. Cronin TW, Marshall NJ, Caldwell RL, Pales D. Compound eyes and ocular pigments of crustacean larvae (Stomatopoda and Decapoda, Brachyura). Mar Freshw Behav Physiol. 1995;26:219-31.

164. Harzsch S, Hafner GS. Evolution of eye development in arthropods: phylogenetic aspects. Arthropod Struct Dev. 2006;35:319-40.

165. Charpentier $\mathrm{CL}$, Cohen $\mathrm{JH}$. Chemical cues from fish heighten visual sensitivity in larval crabs through changes in photoreceptor structure and function. J Exp Biol. 2015;218:3381-90.

166. Fincham A. Ontogeny of anomuran eyes. Symp Zool Soc Lond. 1988:59:123-55

167. Meyer-Rochow VB. Larval and adult eye of the Western Rock Lobster (Panulirus longipes). Cell Tissue Res. 1975;162:439-57.

168. Hafner GS, Tokarski TR. Morphogenesis and pattern formation in the retina of the crayfish Procambarus clarkii. Cell Tissue Res. 1998;293:535-50.

169. Lin C, Cronin TW. Two visual systems in one eyestalk: The unusual optic lobe metamorphosis in the stomatopod Alima pacifica. Dev Neurobiol. 2018;78:3-14

170. Ekerholm M, Hallberg E. Development and growth patterns of olfactory sensilla in malacostracan crustaceans. In: Wiese K, editor. The Crustacean Nervous System. Berlin: Springer; 2002. p. 376-85.

171. Sandeman RE, Sandeman DC. Pre- and postembryonic development, growth and turnover of olfactory receptor neurones in crayfish antennules. J Exp Biol. 1996;199:2409-18.

172. Harzsch S, Krieger J, Faulkes Z. "Crustacea": Decapoda - Astacida. In: Wanninger A, editor. Evolutionary developmental biology of invertebrates 4: Ecdysozoa II: Crustacea. Wien: Springer Verlag; 2015. p. 101-52.

173. Harzsch S, Viertel C. Immunolocalization of neurotransmitters and neuromodulators in the developing crayfish brain. In: Sprecher SG, editor. Brain development: methods and protocols. New York: Springer; 2020 p. 271-91.

174. Loose G, Vogt G, Charmantier-Daures M, Charmantier G, Harzsch S. In: Anger K, Harzsch S, Thiel M, editors. The natural history of the Crustacea, Volume 7: developmental biology and larval ecology. Press: Oxford University; 2020. p. 79-111.

175. Krieger J, Spitzner F. X-ray microscopy of the larval Crustacean brain. In: Sprecher SG, editor. Brain development: methods and protocols. New York: Springer; 2020. p. 253-70.

176. Harzsch S, Dawirs RR. On the morphology of the central nervous system in larval stages of Carcinus maenas L. (Decapoda, Brachyura). Helgolander Meeresunters. 1993;47:61-79.

177. Webster SG, Dircksen H. Putative molt-inhibiting hormone in larvae of the shore crab Carcinus maenas L.: an immunocytochemical approach. Biol Bull. 1991;180:65-71.

178. Chung JS, Webster SG. Expression and release patterns of neuropeptides during embryonic development and hatching of the green shore crab, Carcinus maenas. Development. 2004;131:4751-61.

179. Harzsch S, Dawirs RR. Neurogenesis in larval stages of the spider crab Hyas araneus (Decapoda, Brachyura): proliferation of neuroblasts in the ventral nerve cord. Roux's Arch Dev Biol. 1994;204:93-100.

180. Harzsch S, Dawirs RR. A developmental study of serotonin-immunoreactive neurons in the larval central nervous system of the spider crab Hyas araneus (Decapoda, Brachyura). Invertebrate Neurosci. 1995; 1:53-65.

181. Harzsch S, Dawirs RR. Development of neurons exhibiting Fmrfamiderelated immunoreactivity in the central nervous system of larvae of the spider crab Hyas araneus L. (Decapoda: Majidae). J Crustacean Biol. 1996;16:10.

182. Harzsch S, Dawirs RR. Neurogenesis in the developing crab brain: postembryonic generation of neurons persists beyond metamorphosis. J Neurobiol. 1996;29:384-98.

183. Harzsch S, Miller J, Benton JL, Dawirs RR, Beltz BS. Neurogenesis in the thoracic neuromeres of two crustaceans with different types of metamorphic development. J Exp Biol. 1998;201:2465-79.

184. Geiselbrecht H, Melzer RR. Nervous systems in 3D: A comparison of Caridean, Anomuran, and Brachyuran zoea-l (Decapoda). J Exp Zool B Mol Dev Evol. 2013;320:511-24.

185. Sullivan JM, Macmillan DL. Embryonic and postembryonic neurogenesis in the ventral nerve cord of the freshwater crayfish Cherax destructor. J Exp Zool A Ecol Genet Physiol. 2001;290:49-60.

186. Helluy S, Sandeman RE, Beltz BS, Sandeman DC. Comparative brain ontogeny of the crayfish and clawed lobster: implications of direct and larval development. J Comp Neurol. 1993;335:343-54.

187. Helluy SM, Ruchhoeft ML, Beltz BS. Development of the olfactory and accessory lobes in the American lobster: an allometric analysis and its implications for the deutocerebral structure of decapods. J Comp Neurol. 1995;357:433-45.

188. Beltz BS, Pontes M, Helluy SM, Kravitz EA. Patterns of appearance of serotonin and proctolin immunoreactivities in the developing nervous system of the American lobster. J Neurobiol. 1990;21:521-42.

189. Beltz BS, Helluy SM, Ruchhoeft ML, Gammill LS. Aspects of the embryology and neural development of the American lobster. J Exp Biol. 1992;261:288-97.

190. Cournil I, Casasnovas B, Helluy SM, Beltz BS. Dopamine in the lobster Homarus gammarus: II. Dopamine-immunoreactive neurons and development of the nervous system. J Comp Neurol. 1995;362:1-16.

191. Schneider H, Budhiraja P, Walter I, Beltz BS, Peckol E, Kravitz EA. Developmental expression of the octopamine phenotype in lobsters. Homarus americanus. J Exp Biol. 1996;371:3-14.

192. Scholz NL, Chang ES, Graubard K, Truman JW. The NO/CGMP pathway and the development of neural networks in postembryonic lobsters. J Neurobiol. 1998;34:208-26.

193. Anger K, Püschel C. Growth and exuviation of Norway lobster (Nephrops norvegicus) larvae reared in the laboratory. Ophelia. 1986;25:157-67.

194. Criales MI, Anger K. Experimental studies on the larval development of the shrimps Crangon crangon and C. allmanni. Helgoländer Meeresuntersuch. 1986;40:241-65.

195. Thatje S, Lovrich GA, Torres G, Hagen W, Anger K. Changes in biomass, lipid, fatty acid and elemental composition during abbreviated larval development of the subantarctic shrimp Campylonotus vagans. J Exp Mar Biol Ecol. 2004;301:159-74.

196. Urzúa Á, Anger K. Larval biomass and chemical composition at hatching in two geographically isolated clades of the shrimp Macrobrachium amazonicum: intra- or interspecific variation? Invert Reprod Dev. 2011:55:236-46.

197. González-Ortegón E, Blasco J, Le Vay L, Giménez L. A multiple stressor approach to study the toxicity and sub-lethal effects of pharmaceutical compounds on the larval development of a marine invertebrate. $J$ Hazardous Mat. 2013;263:233-8.

198. González-Ortegón E, Giménez L, Blasco J, Le Vay L. Effects of food limitation and pharmaceutical compounds on the larval development and morphology of Palaemon serratus. Sci Total Environ. 2015;503-504:171-8.

199. Charmantier G, Anger K. Ontogeny of osmoregulation in the palaemonid shrimp Palaemonetes argentinus (Crustacea: Decapoda). Mar Ecol Prog Ser. 1999;181:125-9.

200. González-Ortegón E, Giménez L. Environmentally mediated phenotypic links and performance in larvae of a marine invertebrate. Mar Ecol Prog Ser. 2014;502:185-95.

201. Oliphant A, Thatje S, Brown A, Morini M, Ravaux J, Shillito B. Pressure tolerance of the shallow-water caridean shrimp Palaemonetes varians across its thermal tolerance window. J Exp Biol. 2011;214:1109-17. 
202. Anger K, Harms J. Elemental (CHN) and proximate biochemical composition of decapod crustacean larvae. Comp Biochem Physiol B: Biochem Molec Biol. 1990;97:69-80.

203. Christiansen ME, Anger K. Complete larval development of Galathea intermedia Lilljeborg reared in laboratory culture (Anomura: Galatheidae). J Crustacean Biol. 1990;10:87-111.

204. Anger K. Physiological and biochemical changes during lecithotrophic larval development and early juvenile growth in the northern stone crab, Lithodes maja (Decapoda: Anomura). Mar Biol. 1996;126:283-96.

205. Anger K. Growth and exuvial loss during larval and early juvenile development of the hermit crab Pagurus bernhardus, reared in the laboratory. Mar Biol. 1989;103:503-11

206. Anger K, Harms J, Montu M, Bakker C. Effects of salinity on the larval development of a semiterrestrial tropical crab, Sesarma angustipes (Decapoda: Grapsidae). Mar Ecol-Prog Ser. 1990;62:89-94.

207. Torres G, Anger K, Gimenez L. Effects of osmotic stress on crustacean larval growth and protein and lipid levels are related to life-histories: the genus Armases as a model. Comp BiochemPhysiol B-Biochem Molec Biol. 2007;148:209-24.

208. Cuesta JA, Anger K. Larval morphology and salinity tolerance of a land crab from West Africa, Cardisoma armatum (Brachyura: Grapsoidea: Gecarcinidae). J Crustacean Biol. 2005;25:640-54.

209. Guerao G, Simoni R, Cannicci S, Anger K. Morphological description of the megalopa and the first juvenile crab stage of Chiromantes eulimene (Decapoda, Brachyura, Sesarmidae), with a revision on zoeal morphology. Invert Reprod Dev. 2011;55:100-9.

210. Guerao G, Anger K, Simoni R, Cannicci S. The early life history of Chiromantes ortmanni (Crosnier, 1965) (Decapoda: Brachyura: Sesarmidae): morphology of larval and juvenile stages. Zootaxa. 2012;3347:36-62.

211. Spivak E, Cuesta J. Larval development of Cyrtograpsus affinis (Dana) (Decapoda, Brachyura, Varunidae) from Rio de la Plata estuary, reared in the laboratory. Sci Mar. 2000;64:29-42.

212. Montu M, Anger K, Bakker S. Larval development of the Chinese mitten crab Eriocheir sinensis H. Milne-Edwards (Decapoda: Grapsidae) reared in the laboratory. Helgoländer Meeresuntersuch. 1996;50:223-52.

213. Cuesta JA, Guerao G, Schubart CD, Anger K. Morphology and growth of the larval stages of Geograpsus lividus (Crustacea, Brachyura), with the descriptions of new larval characters for the Grapsidae and an undescribed setation pattern in extended developments. Acta Zool. 2011;92:225.

214. deBakker C, Montu M, Anger K, Loureiro-Fernandes LL. Larval development of Hexapanopeus schmitti Rathbun, 1930 (Decapoda, Brachyura, Xanthidae) reared in the laboratory. Neritica. 1989;4:137-64.

215. Anger K. Development and growth in larval and juvenile Hyas coarctatus (Decapoda, Majidae) reared in the laboratory. Mar Ecol Progr Ser. 1984;19:115-23.

216. Anger K. Growth and elemental composition (C, N, H) in Inachus dorsettensis (Decapoda: Majidae) larvae reared in the laboratory. Mar Biol. 1988;99:255-60

217. Anger K, Dawirs RR, Anger V, Goy JW, Costlow JD. Starvation resistence in first stage zoeae of brachyuran crabs in relation to temperature. $J$ Crustacean Biol. 1981;1:518-25.

218. Anger K, Harms J, Montu M, Bakker C. Growth and respiration during the larval development of a tropical spider crab, Libinia ferreirae (Decapoda: Majidae). Mar Ecol Prog Ser. 1989;54:43-50.

219. Harms J. Accumulation and loss of biomass in Liocarcinus holsatus larvae during growth and exuviation. Mar Biol. 1990;104:183-90.
220. Harms J, Seeger B. Larval development and survival in seven decapod species (Crustacea) in relation to laboratory diet. J Exp Mar Bio Ecol. 1989:133:129-39.

221. Andrés M, Estévez A, Anger K, Rotllant G. Developmental patterns of larval growth in the edible spider crab, Maja brachydactyla (Decapoda: Majidae). J Exp Mar Bio Ecol. 2008;357:35-40.

222. Montu M, Anger $\mathrm{K}$, de Bakker C. Variability in the larval development of Metasesarma rubripes (Decapoda, Grapsidae) reared in the laboratory. Neritica. 1990:5:113-8.

223. Anger K, Ismael D. Growth and elemental composition (C, N, H) in larvae and early juveniles of a South American salt marsh crab, Chasmagnathus granulata (Decapoda: Grapsidae). Mangrove Salt Marshes. 1997:1:219-27.

224. Montu M, Anger K, Bakker C, Anger V, Loureiro FL. Larval development of the Brazilian mud crab Panopeus austrobesus Williams, 1983 (Decapoda: Xanthidae) reared in the laboratory. J Crustacean Biol. 1988;8:594-613.

225. Guerao G, Anger K, Nettelmann U, Schubart CD. Complete larval and early juvenile development of the mangrove crab Perisesarma fasciatum (Crustacea: Brachyura: Sesarmidae) from Singapore, with a larval comparison of Parasesarma and Perisesarma. J Plankton Res. 2004;26:1389-408.

226. Gebauer P, Paschke K, Anger K. Seasonal variation in the nutritional vulnerability of first-stage larval porcelain crab, Petrolisthes laevigatus (Anomura: Porcellanidae) in southern Chile. J Exp Mar Bio Ecol. 2010. https://doi.org/10.1016/j.jembe.2010.02.016.

227. Pardo LM, Véliz D, Wehrtmann IS, Anger K. Effects of starvation periods on growth of zoea I. in Petrolisthes violaceus (Guérin, 1831) (Decapoda: Anomura: Porcellanidae). Investigaciones Marinas Valparaiso (Chile). 1997;25:255-62.

228. Anger K. Starvation resistance in larvae of a semiterrestrial crab, Sesarma curacaoense (Decapoda: Grapsidae). J Exp Mar Bio Ecol. 1995;187:161-74.

229. Anger K, Schubart CD. Experimental evidence of food-independent larval development in endemic Jamaican freshwater-breeding crabs. Physiol Biochem Zool. 2005;78:246-58.

230. Anger K. The early life history of Sesarma fossarum, an endemic freshwater crab from Jamaica. Invertebr Reprod Dev. 2005;47:63-72.

231. Anger K, Moreira GS. Biomass and elemental composition of eggs and larvae of a mangrove crab, Sesarma rectum Randall (Decapoda: Sesarmidae) and comparison to a related species with abbreviated larval development. Sci Mar. 2004;68:117-26.

232. Anger K, Montu M, Bakker C, Loureiro Fernandes LL. Larval development of Uca thayeri Rathbun, 1900 (Decapoda: Ocypodidae) reared in the laboratory. Meeresforschung. 1990;32:276-94.

233. Rice Al, Ingle RW. The larval development of Carcinus maenas (L.) and C. mediterraneus Czerniavsky (Crustacea, Brachyura, Portunidae) reared in the laboratory. Bull Br Mus Nat Hist. 1975;28:103-19.

\section{Publisher's Note}

Springer Nature remains neutral with regard to jurisdictional claims in published maps and institutional affiliations.

Ready to submit your research? Choose BMC and benefit from:

- fast, convenient online submission

- thorough peer review by experienced researchers in your field

- rapid publication on acceptance

- support for research data, including large and complex data types

- gold Open Access which fosters wider collaboration and increased citations

- maximum visibility for your research: over $100 \mathrm{M}$ website views per year

At BMC, research is always in progress.

Learn more biomedcentral.com/submissions 